\title{
Source rock characterization of mesozoic to cenozoic organic matter rich marls and shales of the Eratosthenes Seamount, Eastern Mediterranean Sea
}

Sebastian Grohmann ${ }^{1,2,3,}{ }^{*}$, Susanne W. Fietz ${ }^{1,4}$, Ralf Littke ${ }^{1}$, Samer Bou Daher ${ }^{1,5}$, Maria Fernanda Romero-Sarmiento ${ }^{2}$, Fadi Henri Nader ${ }^{2}$, and Francois Baudin ${ }^{3}$

${ }^{1}$ Energy \& Mineral Resources Group (EMR), Institute of Geology and Geochemistry of Petroleum and Coal, RWTH Aachen University, Lochnerstrasse 4-20, 52056 Aachen, Germany

${ }^{2}$ Division of Geosciences, IFP Energies nouvelles (IFPEN), 1-4 avenue de Bois-Préau, 92852 Rueil-Malmaison Cedex, France

${ }^{3}$ Institut des Sciences de la Terre de Paris, Sorbonne Université, 4 place Jussieu, 75005 Paris, France

${ }^{4}$ Applied Research in Ichnology and Sedimentology (ARISE) Group, Department of Earth Sciences, Simon Fraser University, 8888 University Drive, Burnaby, British Columbia V5A 1S6, Canada

${ }^{5}$ Department of Geosciences and Natural Resource Management, University of Copenhagen, Øster Volgade 10, 1350 Copenhagen, Denmark

Received: 30 March 2018 / Accepted: 12 July 2018

\begin{abstract}
Several significant hydrocarbon accumulations were discovered over the past decade in the Levant Basin, Eastern Mediterranean Sea. Onshore studies have investigated potential source rock intervals to the east and south of the Levant Basin, whereas its offshore western margin is still relatively underexplored. Only a few cores were recovered from four boreholes offshore southern Cyprus by the Ocean Drilling Program (ODP) during the drilling campaign Leg 160 in 1995. These wells transect the Eratosthenes Seamount, a drowned bathymetric high, and recovered a thick sequence of both pre- and post-Messinian sedimentary rocks, containing mainly marine marls and shales. In this study, 122 core samples of Late Cretaceous to Messinian age were analyzed in order to identify organic-matter-rich intervals and to determine their depositional environment as well as their source rock potential and thermal maturity. Both Total Organic and Inorganic Carbon (TOC, TIC) analyses as well as Rock-Eval pyrolysis were firstly performed for the complete set of samples whereas Total Sulfur (TS) analysis was only carried out on samples containing significant amount of organic matter (>0.3 wt.\% TOC). Based on the Rock-Eval results, eight samples were selected for organic petrographic investigations and twelve samples for analysis of major aliphatic hydrocarbon compounds. The organic content is highly variable in the analyzed samples (0-9.3 wt.\%). TS/TOC as well as several biomarker ratios (e.g. $\mathrm{Pr} / \mathrm{Ph}<2)$ indicate a deposition under dysoxic conditions for the organic matter-rich sections, which were probably reached during sporadically active upwelling periods. Results prove potential oil prone Type II kerogen source rock intervals of fair to very good quality being present in Turonian to Coniacian (average: $\mathrm{TOC}=0.93 \mathrm{wt} . \%, \mathrm{HI}=319 \mathrm{mg} \mathrm{HC} / \mathrm{g} \mathrm{TOC}$ ) and in Bartonian to Priabonian (average: $\mathrm{TOC}=4.8 \mathrm{wt} . \%$, $\mathrm{HI}=469 \mathrm{mg} \mathrm{HC} / \mathrm{g}$ TOC) intervals. A precise determination of the actual source rock thickness is prevented by low core recovery rates for the respective intervals. All analyzed samples are immature to early mature. However, the presence of deeper buried, thermally mature source rocks and hydrocarbon migration is indicated by the observation of solid bitumen impregnation in one Upper Cretaceous and in one Lower Eocene sample.
\end{abstract}

\section{Introduction}

Significant natural gas discoveries (e.g. Dalit, Tamar, Leviathan, Aphrodite, Zohr and recently Calypso fields) in the last decade have rendered the Levant Basin in the

\footnotetext{
* Corresponding author:

Sebastian.grohmann@emr.rwth-aachen.de
}

Eastern Mediterranean Sea as one of the most promising frontier basins of the world (e.g. Needham et al., 2013; Ratner, 2016; Eni, 2018) (Fig. 1). The reservoir units of these gas plays are Oligocene to Miocene sandstones (Montadert et al., 2014; Bou Daher et al., 2016) and Cretaceous to Miocene shallow water carbonate build-ups (Bertello et al., 2016; Esestime et al., 2016). Onshore studies have identified several events of source rock deposition in 

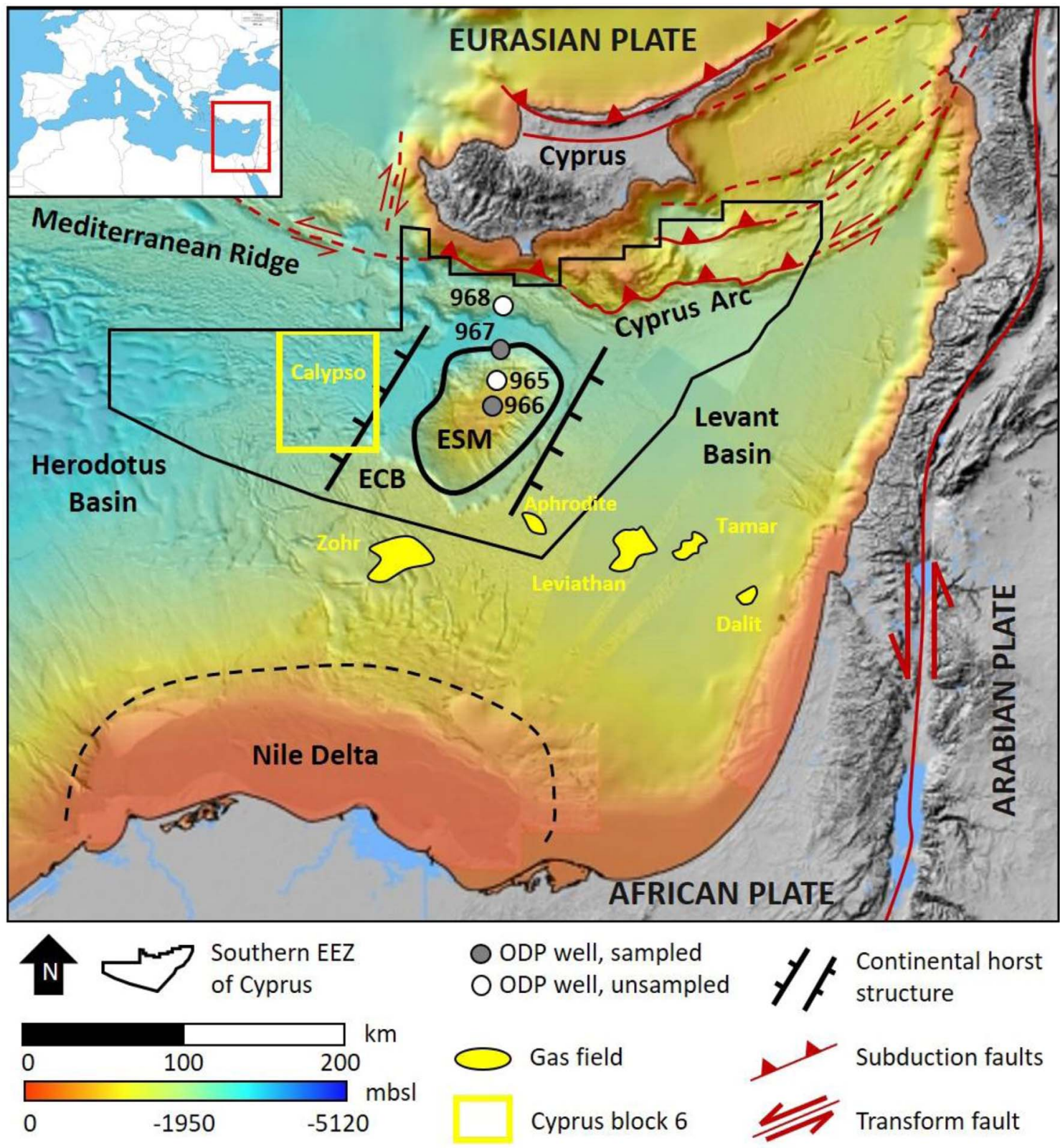

Fig. 1. Overview of the study area. Onshore areas colored in grey, subsea bathymetry colored in shades according to scale. Marked gas fields (yellow) represent recent discoveries. The area is mainly controlled by the interplay of the African, Arabian, and Eurasian plates. The Eratosthenes Seamount (ESM) represents a large carbonate platform which is located on the underlying, larger Eratosthenes Continental Block (ECB). The southern Exclusive Economic Zone (EEZ) of Cyprus represents the available blocks for hydrocarbon exploration. The samples of this study were collected from the cores that were drilled along the northern slope of the ESM during the ODO Leg 160 campaign. Modified after Hawie et al. (2013) and Symeou et al. (2018).

the sedimentary succession of the eastern and southern Levant margin which may also extend into the western offshore part of the basin (Beydoun, 1991; May, 1991; Vandré et al., 2007; Naylor et al., 2013; Bou Daher et al., 2014, Bou Daher et al., 2015). The potential of working petroleum systems along the western margin of the Levant Basin is inferred from high resolution seismic data indicating sufficient thickness of the sedimentary column, alternating sealing units, as well as direct hydrocarbon indicators, e.g. bright spots and gas chimneys (Roberts and Peace, 2007; Montadert et al., 2014). To date, only south of Cyprus' southern Exclusive Economic Zone, sea bottom sampling in the North East Nile Delta offshore Egypt proves that multiple source rocks participate in thermogenic hydrocarbon charge (Shaaban et al., 2006; Montadert et al., 2014). However, these source rock intervals were drilled in shallow waters close to the coast. Further they are still poorly described, and do not necessarily correlate with the deeper offshore.

Four locations were core drilled in the area of Cyprus by the Ocean Drilling Program (ODP) during the Leg 160 campaign in 1995 (Emeis et al., 1996). The well sites 
penetrate the northern flank of the Eratosthenes Seamount (ESM) which is located offshore southern Cyprus (Fig. 1). Organic Matter $(\mathrm{OM})$ rich intervals were noticed in the sedimentary succession of the retrieved cores (Emeis et al., 1996). However, barely any detailed organic geochemical analysis has been performed on the pre-Messinian rocks of these cores, hitherto, whereas numerous organic geochemical studies were conducted and published on the young, post-Messinian Mediterranean sapropels. An exception is one sample of middle Eocene age (160-966F-26R-1, $17-22 \mathrm{~cm}$ ) that reveals a TOC value of $5.25 \mathrm{wt} . \%$, Hydrogen and Oxygen Index values of $429 \mathrm{mg} \mathrm{HC} / \mathrm{g}$ TOC and $63 \mathrm{mg} \mathrm{CO}_{2} / \mathrm{g}$ TOC, respectively, as well as a $T_{\max }$ of $413{ }^{\circ} \mathrm{C}$ (Emeis et al., 1996). These results support the assumption that the organic rich intervals in these cores might have significant source rock potential.

For petroleum system perspectives, the purpose of this paper is to provide more potential source rock information about the overall underexplored western margin of the Levant Basin. In this way, sub-Messinian organic-rich rock intervals of the ODP Leg 160 cores were sampled and analyzed in order to investigate the depositional environment, source rock quality as well as thermal maturity of the sedimentary organic matter.

\section{Geological background}

The Eratosthenes Seamount (ESM) is a bathymetric high that rises about $1500 \mathrm{~m}$ above its surrounding sea floor with its summit $700 \mathrm{~m}$ below sea level (Fig. 1) (Galindo-Zaldivar et al., 2001). Its northeast-southwest and northwestsoutheast extension reaches approximately $110 \mathrm{~km}$ and $80 \mathrm{~km}$, respectively. The ESM is located on the bigger Eratosthenes Continental Block (ECB) which is a continental fragment that was separated from the Afro-Arabian margin during the disintegration of Gondwana. It is believed to have rifted westwards along NNE-SSW oriented transform faults during the Triassic to Early Jurassic (Robertson, 1998a; Gardosh and Druckman, 2006; Netzeband et al., 2006; Segev and Rybakov, 2010; Ghalayini et al., 2014; Montadert et al., 2014). Between the ECB and the AfroArabian continental margin, a southern arm of the NeoTethys evolved which later formed the Levant Basin (Gardosh and Druckman, 2006). From the Late Cretaceous onwards, the entire region was affected by the convergence of Eurasia and Afro-Arabia, which resulted in northward subduction and the creation of the Cyprus Arc (Hawie et al., 2013; Montadert et al., 2014). As a consequence, the ESM is in a state of collision with the island of Cyprus since the Pliocene (Robertson, 1998a; Galindo-Zaldivar et al., 2001).

The sedimentary cover of the ESM is approximately $6 \mathrm{~km}$ thick (Montadert et al., 2014; Papadimitriou et al., 2018). Only the upper 600 meters below the seafloor (mbsf) were cored during the ODP drilling campaign Leg 160 (Emeis et al., 1996). Undrilled sediments are inferred from seismic reflection and are interpreted to comprise syn-rift sediments (volcaniclastics, carbonates or clastic sediments) which are overlain by a thick post-rift succession of extensive shallow marine carbonate build-ups, intercalated with a sequence of undisturbed, probably fine-grained, marine sediments (Montadert et al., 2014). A schematic overview of the lithostratigraphy of the ESM, the Levant Basin, as well as the well-constrained sedimentary pile of the eastern margin of the Levant Basin in northern and southern Lebanon are shown in Figure 2. Analysis of the drilled intervals from the ODP Leg 160 campaign constrains the interpretation of the depositional environments of the Upper Cretaceous and younger strata (Emeis et al., 1996; Premoli-Silva et al., 1998; Staerker, 1998). Shallow water carbonate deposition was interrupted during the Cenomanian/Turonian and younger Upper Cretaceous sediments were deposited in a hemipelagic to pelagic environment (Robertson, 1998c). Later, Miocene shallow water carbonate build-ups formed on the ESM. During the Messinian Salinity Crisis (MSC) the sediments of the ESM were most likely exposed and affected by extensive meteoric water flushing, karstification, dolomitization, as well as erosion (Robertson, 1998b). Subsequent drowning of the ESM during the Pliocene to Quaternary enabled the deposition of pelagic carbonates and sapropels (Robertson, 1998c).

\section{Materials and methods}

\subsection{Samples}

Samples were collected from Site 966, hole F, and Site 967, holes A and E (Tab. 1). The borehole cores were drilled at the northern slope (Site 967) and the top of the platform (Site 966) of the ESM (Fig. 1) by the Ocean Drilling Program (ODP) during the expedition Leg 160 in 1995. Lithology of these cores is described in the initial shipboard scientific results (Emeis et al., 1996). In total, 122 samples were sampled (Tab. 1); 120 samples were collected at irregular intervals from brownish-grey to black marls, shaly marls, and carbonates and two solid bitumen-impregnated samples (15/891 and 15/896; Lower Eocene and Upper Cretaceous, respectively) were retrieved from light grey marls. Biostratigraphic age determination of the cores was previously conducted by Premoli-Silva et al. (1998) and Staerker (1998). Their results were adapted to the Chronostratigraphic Chart 2015 for this study; 20 samples are assigned to upper Turonian to Coniacian, 6 to Santonian, 11 to Campanian to Maastrichtian, 3 to Eocene to Miocene, 50 to Ypresian to Lutetian, 29 to Bartonian to Priabonian, and 3 samples to the Messinian age.

All further processing and analyses of the collected samples were done at the Institute of Geology and Geochemistry of Petroleum and Coal, RWTH Aachen University.

\subsection{Elemental analyses and Rock-Eval pyrolysis}

Total Organic (TOC) and Inorganic Carbon (TIC) measurements were performed on all samples using a liquiTOC II analyzer in order to quantify the amounts of OM and carbonates. The applied "temperature ramp method" enables direct measurement of the carbon content of each sample without previous acidification. The sample powder (100 mg) is heated to $550{ }^{\circ} \mathrm{C}$ and kept at this temperature 


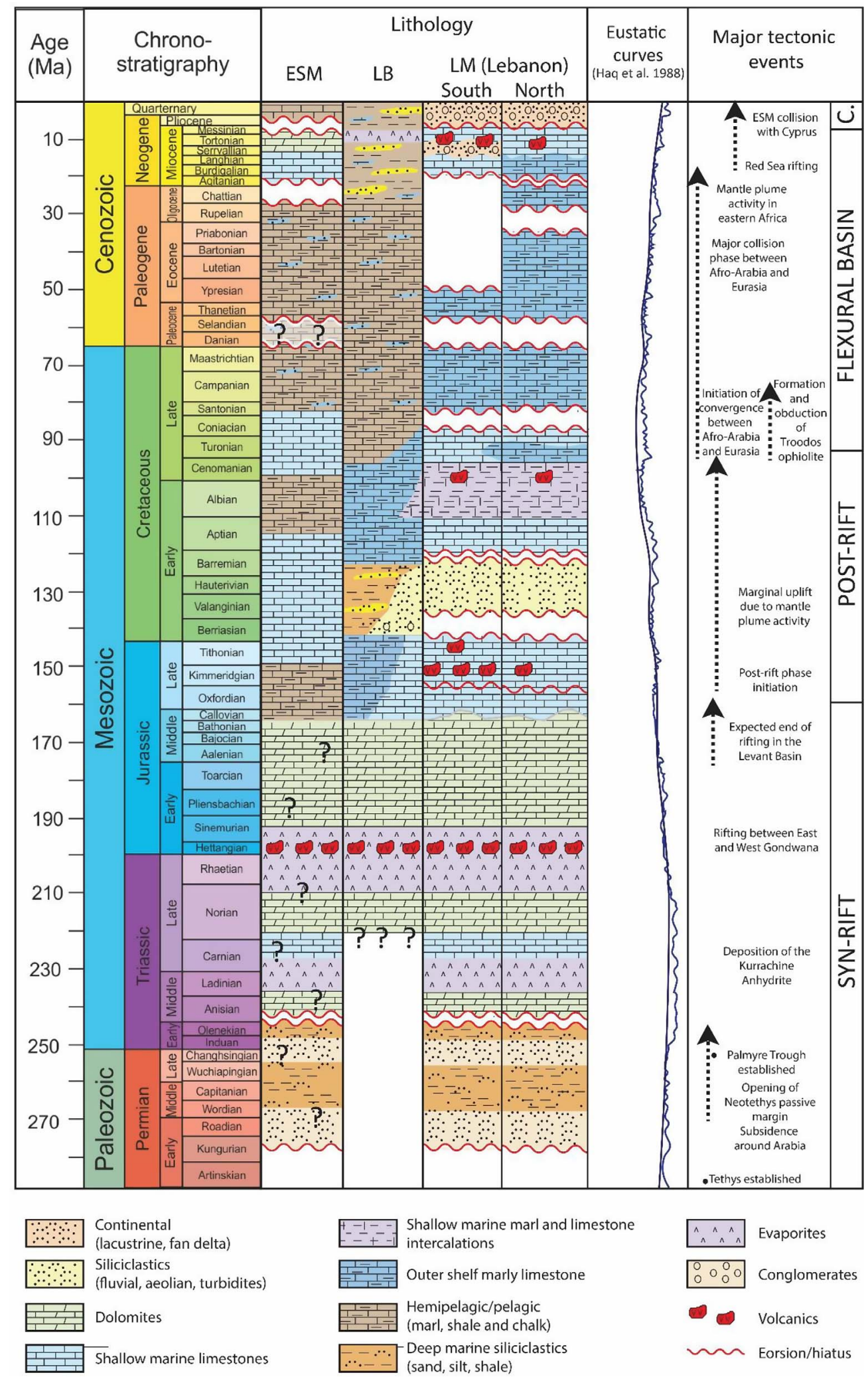

Fig. 2. Schematic overview of the sedimentary successions to be found in the Levant Basin (LB), the Eratosthenes Seamount (ESM) and at the Levant margin (LM) along Lebanon. Modified after Bou Daher et al. (2016). 
Table 1. Samples obtained from the OPD Leg 160 campaign along the Eratosthenes Seamount (offshore Cyprus) and the respective core interval, ordered by age.

\begin{tabular}{|c|c|c|c|c|}
\hline Sample & Site-hole & Core & Depth [mbsf] & Age \\
\hline $15 / 892$ & $967-\mathrm{A}$ & 13 & 117.38 & Messinian \\
\hline $15 / 893$ & $967-\mathrm{A}$ & 13 & 120.97 & Messinian \\
\hline $15 / 894$ & $967-\mathrm{A}$ & 13 & 122.05 & Messinian \\
\hline $17 / 1679$ & $966-\mathrm{F}$ & 26 & 298.48 & Bartonian to Priabonian \\
\hline $15 / 863$ & $966-\mathrm{F}$ & 26 & 298.53 & Bartonian to Priabonian \\
\hline $17 / 1680$ & $966-\mathrm{F}$ & 26 & 298.56 & Bartonian to Priabonian \\
\hline $17 / 1681$ & $966-\mathrm{F}$ & 26 & 298.61 & Bartonian to Priabonian \\
\hline $15 / 864$ & $966-\mathrm{F}$ & 26 & 298.66 & Bartonian to Priabonian \\
\hline $17 / 1682$ & $966-\mathrm{F}$ & 26 & 298.72 & Bartonian to Priabonian \\
\hline $15 / 865$ & $966-\mathrm{F}$ & 26 & 298.76 & Bartonian to Priabonian \\
\hline $17 / 1683$ & $966-\mathrm{F}$ & 26 & 298.86 & Bartonian to Priabonian \\
\hline $15 / 866$ & $966-\mathrm{F}$ & 26 & 298.90 & Bartonian to Priabonian \\
\hline $15 / 867$ & $966-\mathrm{F}$ & 26 & 299.09 & Bartonian to Priabonian \\
\hline $17 / 1685$ & $966-\mathrm{F}$ & 26 & 299.11 & Bartonian to Priabonian \\
\hline $17 / 1686$ & $966-\mathrm{F}$ & 26 & 299.19 & Bartonian to Priabonian \\
\hline $15 / 868$ & $966-\mathrm{F}$ & 26 & 299.21 & Bartonian to Priabonian \\
\hline $15 / 869$ & $966-\mathrm{F}$ & 26 & 299.28 & Bartonian to Priabonian \\
\hline $17 / 1687$ & $966-\mathrm{F}$ & 26 & 299.35 & Bartonian to Priabonian \\
\hline $15 / 870$ & $966-\mathrm{F}$ & 26 & 299.40 & Bartonian to Priabonian \\
\hline $17 / 1688$ & $966-\mathrm{F}$ & 26 & 299.46 & Bartonian to Priabonian \\
\hline $15 / 871$ & $966-\mathrm{F}$ & 26 & 299.50 & Bartonian to Priabonian \\
\hline $17 / 1689$ & $966-\mathrm{F}$ & 26 & 299.56 & Bartonian to Priabonian \\
\hline $15 / 872$ & $966-\mathrm{F}$ & 26 & 299.59 & Bartonian to Priabonian \\
\hline $15 / 873$ & $966-\mathrm{F}$ & 26 & 299.66 & Bartonian to Priabonian \\
\hline $17 / 1690$ & $966-\mathrm{F}$ & 26 & 299.71 & Bartonian to Priabonian \\
\hline $15 / 874$ & $966-\mathrm{F}$ & 26 & 299.76 & Bartonian to Priabonian \\
\hline $17 / 1691$ & $966-\mathrm{F}$ & 26 & 299.82 & Bartonian to Priabonian \\
\hline $17 / 1692$ & $966-\mathrm{F}$ & 26 & 300.05 & Bartonian to Priabonian \\
\hline $15 / 875$ & $966-\mathrm{F}$ & 26 & 300.84 & Bartonian to Priabonian \\
\hline $17 / 1693$ & $966-\mathrm{F}$ & 26 & 301.03 & Bartonian to Priabonian \\
\hline $15 / 876$ & $966-\mathrm{F}$ & 26 & 301.11 & Bartonian to Priabonian \\
\hline $17 / 1694$ & $966-\mathrm{F}$ & 26 & 301.18 & Bartonian to Priabonian \\
\hline $15 / 877$ & $966-\mathrm{F}$ & 27 & 314.97 & Ypresian to Lutetian \\
\hline $17 / 1696$ & $966-\mathrm{F}$ & 28 & 317.8 & Ypresian to Lutetian \\
\hline $17 / 1698$ & $966-\mathrm{F}$ & 28 & 318.46 & Ypresian to Lutetian \\
\hline $17 / 1699$ & $966-\mathrm{F}$ & 28 & 318.73 & Ypresian to Lutetian \\
\hline $17 / 1700$ & $966-\mathrm{F}$ & 28 & 319.20 & Ypresian to Lutetian \\
\hline $17 / 1701$ & $966-\mathrm{F}$ & 28 & 319.60 & Ypresian to Lutetian \\
\hline $17 / 1702$ & $966-\mathrm{F}$ & 28 & 320.72 & Ypresian to Lutetian \\
\hline $17 / 1703$ & $966-\mathrm{F}$ & 28 & 320.92 & Ypresian to Lutetian \\
\hline $17 / 1704$ & $966-\mathrm{F}$ & 28 & 321.29 & Ypresian to Lutetian \\
\hline $17 / 1705$ & $966-\mathrm{F}$ & 28 & 321.63 & Ypresian to Lutetian \\
\hline $17 / 1706$ & $966-\mathrm{F}$ & 28 & 322.13 & Ypresian to Lutetian \\
\hline $17 / 1707$ & $966-\mathrm{F}$ & 28 & 323.28 & Ypresian to Lutetian \\
\hline $17 / 1708$ & $966-\mathrm{F}$ & 28 & 324.23 & Ypresian to Lutetian \\
\hline $17 / 1709$ & $966-\mathrm{F}$ & 29 & 327.49 & Ypresian to Lutetian \\
\hline
\end{tabular}


Table 1. (continued).

\begin{tabular}{|c|c|c|c|c|}
\hline Sample & Site-hole & Core & Depth [mbsf] & Age \\
\hline$\overline{17 / 1711}$ & $966-\mathrm{F}$ & 29 & 329.07 & Ypresian to Lutetian \\
\hline $17 / 1712$ & $966-\mathrm{F}$ & 29 & 329.27 & Ypresian to Lutetian \\
\hline $17 / 1715$ & $966-\mathrm{F}$ & 29 & 330.60 & Ypresian to Lutetian \\
\hline $15 / 878$ & $966-\mathrm{F}$ & 30 & 337.10 & Ypresian to Lutetian \\
\hline $17 / 1717$ & $966-\mathrm{F}$ & 30 & 337.18 & Ypresian to Lutetian \\
\hline $15 / 879$ & $966-\mathrm{F}$ & 30 & 337.25 & Ypresian to Lutetian \\
\hline $15 / 880$ & $966-\mathrm{F}$ & 30 & 337.40 & Ypresian to Lutetian \\
\hline $15 / 881$ & $966-\mathrm{F}$ & 30 & 337.50 & Ypresian to Lutetian \\
\hline $17 / 1718$ & $966-\mathrm{F}$ & 30 & 337.51 & Ypresian to Lutetian \\
\hline $15 / 882$ & $966-\mathrm{F}$ & 30 & 337.62 & Ypresian to Lutetian \\
\hline $15 / 883$ & $966-\mathrm{F}$ & 30 & 337.70 & Ypresian to Lutetian \\
\hline $15 / 884$ & $966-\mathrm{F}$ & 30 & 338.03 & Ypresian to Lutetian \\
\hline $17 / 1720$ & $966-\mathrm{F}$ & 30 & 338.12 & Ypresian to Lutetian \\
\hline $17 / 1721$ & $966-\mathrm{F}$ & 30 & 338.40 & Ypresian to Lutetian \\
\hline $15 / 885$ & $966-\mathrm{F}$ & 30 & 338.77 & Ypresian to Lutetian \\
\hline $15 / 886$ & $966-\mathrm{F}$ & 30 & 338.85 & Ypresian to Lutetian \\
\hline $17 / 1722$ & $966-\mathrm{F}$ & 30 & 338.85 & Ypresian to Lutetian \\
\hline $15 / 887$ & $966-\mathrm{F}$ & 30 & 339.32 & Ypresian to Lutetian \\
\hline $17 / 1724$ & $966-\mathrm{F}$ & 30 & 339.55 & Ypresian to Lutetian \\
\hline $15 / 888$ & $966-\mathrm{F}$ & 30 & 339.64 & Ypresian to Lutetian \\
\hline $17 / 1725$ & $966-\mathrm{F}$ & 30 & 339.66 & Ypresian to Lutetian \\
\hline $17 / 1726$ & $966-\mathrm{F}$ & 30 & 339.78 & Ypresian to Lutetian \\
\hline $15 / 889$ & $966-\mathrm{F}$ & 30 & 339.81 & Ypresian to Lutetian \\
\hline $17 / 1727$ & $966-\mathrm{F}$ & 30 & 339.89 & Ypresian to Lutetian \\
\hline $15 / 890$ & $966-\mathrm{F}$ & 30 & 339.94 & Ypresian to Lutetian \\
\hline $15 / 891$ & $966-\mathrm{F}$ & 30 & 340.03 & Ypresian to Lutetian \\
\hline $17 / 1729$ & $966-\mathrm{F}$ & 30 & 340.53 & Ypresian to Lutetian \\
\hline $17 / 1732$ & $966-\mathrm{F}$ & 30 & 341.07 & Ypresian to Lutetian \\
\hline $17 / 1733$ & $966-\mathrm{F}$ & 31 & 346.43 & Ypresian to Lutetian \\
\hline $17 / 1735$ & $966-\mathrm{F}$ & 31 & 347.02 & Ypresian to Lutetian \\
\hline $17 / 1736$ & $966-\mathrm{F}$ & 31 & 347.76 & Ypresian to Lutetian \\
\hline $17 / 1737$ & $966-\mathrm{F}$ & 31 & 347.96 & Ypresian to Lutetian \\
\hline $17 / 1738$ & $966-\mathrm{F}$ & 31 & 348.47 & Ypresian to Lutetian \\
\hline $17 / 1740$ & $966-\mathrm{F}$ & 31 & 348.80 & Ypresian to Lutetian \\
\hline $17 / 1742$ & $966-\mathrm{F}$ & 31 & 349.53 & Ypresian to Lutetian \\
\hline $17 / 1743$ & $966-\mathrm{F}$ & 31 & 349.92 & Ypresian to Lutetian \\
\hline $15 / 895$ & $967-\mathrm{E}$ & 6 & 160.93 & Eocene to Miocene \\
\hline $17 / 1744$ & $967-\mathrm{E}$ & 7 & 167.30 & early Oligocene \\
\hline $17 / 1745$ & $967-\mathrm{E}$ & 7 & 167.79 & early Oligocene \\
\hline $17 / 1746$ & $967-\mathrm{E}$ & 8 & 177.05 & Maastrichtian \\
\hline $17 / 1747$ & $967-\mathrm{E}$ & 8 & 177.32 & Campanian \\
\hline $17 / 1748$ & $967-\mathrm{E}$ & 8 & 177.43 & Campanian \\
\hline $15 / 896$ & $967-\mathrm{E}$ & 17 & 265.49 & Campanian \\
\hline $17 / 1749$ & $967-\mathrm{E}$ & 18 & 273.27 & Campanian \\
\hline $17 / 1751$ & $967-\mathrm{E}$ & 18 & 274.06 & Campanian \\
\hline $17 / 1752$ & $967-\mathrm{E}$ & 18 & 274.36 & Campanian \\
\hline $17 / 1753$ & $967-\mathrm{E}$ & 18 & 274.65 & Campanian \\
\hline
\end{tabular}


Table 1. (continued).

\begin{tabular}{|c|c|c|c|c|}
\hline Sample & Site-hole & Core & Depth [mbsf] & Age \\
\hline $17 / 1754$ & $967-\mathrm{E}$ & 18 & 275.04 & Campanian \\
\hline $17 / 1755$ & $967-\mathrm{E}$ & 18 & 275.55 & Campanian \\
\hline $17 / 1756$ & $967-\mathrm{E}$ & 18 & 276.31 & Campanian \\
\hline $17 / 1757$ & $967-\mathrm{E}$ & 25 & 340.93 & Santonian \\
\hline $17 / 1758$ & $967-\mathrm{E}$ & 25 & 341.34 & Santonian \\
\hline $17 / 1759$ & $967-\mathrm{E}$ & 25 & 342.18 & Santonian \\
\hline $17 / 1760$ & $967-\mathrm{E}$ & 25 & 342.80 & Santonian \\
\hline $17 / 1761$ & $967-\mathrm{E}$ & 25 & 343.11 & Santonian \\
\hline $17 / 1762$ & $967-\mathrm{E}$ & 25 & 344.40 & Santonian \\
\hline $15 / 897$ & $967-\mathrm{E}$ & 28 & 369.44 & Coniacian \\
\hline $15 / 898$ & $967-\mathrm{E}$ & 28 & 370.06 & Coniacian \\
\hline $15 / 899$ & $967-\mathrm{E}$ & 28 & 370.40 & Coniacian \\
\hline $17 / 1763$ & $967-\mathrm{E}$ & 29 & 379.22 & Coniacian \\
\hline $15 / 900$ & $967-\mathrm{E}$ & 29 & 379.71 & Coniacian \\
\hline $17 / 1764$ & $967-\mathrm{E}$ & 29 & 379.87 & Coniacian \\
\hline $15 / 901$ & $967-\mathrm{E}$ & 29 & 379.96 & Coniacian \\
\hline $17 / 1765$ & $967-\mathrm{E}$ & 29 & 379.98 & Turonian \\
\hline $15 / 902$ & $967-\mathrm{E}$ & 29 & 380.28 & Turonian \\
\hline $17 / 1766$ & $967-\mathrm{E}$ & 29 & 380.30 & Turonian \\
\hline $15 / 903$ & $967-\mathrm{E}$ & 29 & 380.36 & Turonian \\
\hline $17 / 1767$ & $967-\mathrm{E}$ & 29 & 380.54 & Turonian \\
\hline $15 / 904$ & $967-\mathrm{E}$ & 29 & 380.77 & Turonian \\
\hline $15 / 905$ & $967-\mathrm{E}$ & 29 & 380.80 & Turonian \\
\hline $17 / 1768$ & $967-\mathrm{E}$ & 29 & 380.94 & Turonian \\
\hline $15 / 906$ & $967-\mathrm{E}$ & 29 & 381.13 & Turonian \\
\hline $17 / 1769$ & $967-\mathrm{E}$ & 30 & 388.46 & Turonian \\
\hline $17 / 1770$ & $967-\mathrm{E}$ & 30 & 388.67 & Turonian \\
\hline $17 / 1771$ & $967-\mathrm{E}$ & 30 & 388.70 & Turonian \\
\hline $17 / 1772$ & $967-\mathrm{E}$ & 30 & 388.82 & Turonian \\
\hline
\end{tabular}

for $600 \mathrm{~s}$. Subsequent cooling of the sample to $400{ }^{\circ} \mathrm{C}$ is followed by a second step of heating until the sample reaches $1000{ }^{\circ} \mathrm{C}$ where it remains for $400 \mathrm{~s}$. The released $\mathrm{CO}_{2}$ is detected at each step by an infrared cell (detection limit $10 \mathrm{ppm}$, relative TOC error $0.6 \mathrm{wt} . \%$, relative TIC error 1.7 wt.\%). We already know that thermally less stable carbonates (such as siderite) might decompose already at temperatures around $500{ }^{\circ} \mathrm{C}$ and might lead to an overestimation of the TOC and an underestimation of the TIC content, respectively (Pillot et al., 2014). However, the marine carbonates investigated in this study are mostly free of siderite.

$\mathrm{CaCO}_{3}$ percentage was calculated using $\mathrm{CaCO}_{3}=$ TIC.8.333 (Littke, 1993). Carbonate content of samples from dolomite-dominated intervals was calculated with the equation $\mathrm{CaMg}\left(\mathrm{CO}_{3}\right)_{2}=$ TIC.7.8333 (Bou Daher et al., 2014).

For interpreting the depositional environment and paleo-redox conditions the TS content was determined for samples containing $>0.3 \mathrm{wt} . \%$ TOC using a LECO S200 analyzer with an infrared detector (detection limit of $20 \mathrm{ppm}$, relative error of $<5 \%$ ).
Rock-Eval pyrolysis (Espitalié et al., 1977) was applied for 122 samples to qualify the hydrogen and oxygen content of the $\mathrm{OM}$ and its thermal maturity. However, only 104 samples provided useful results. Measurements were performed on a classic Rock-Eval 6 instrument (Behar et al., 2001) using the standard Basic/Bulk-Rock method described in Espitalié et al. (1977) and Behar et al. (2001). Approximately $120 \mathrm{mg}$ sample powder was taken for samples with TOC values ranging from $0.1 \mathrm{wt} . \%$ to $2.0 \mathrm{wt} . \%, 100 \mathrm{mg}$ powder for samples with TOC values between 2 wt. $\%$ and 8 wt. $\%$ and $50 \mathrm{mg}$ for samples showing TOC values between 8 wt. $\%$ and 20 wt.\%. Approximately $50 \mathrm{mg}$ of silica was added to sample quantities of $<50 \mathrm{mg}$. Standard Rock-Eval parameters like S1, S2, S3, $T_{\max }$ as well as Hydrogen Index (HI), Oxygen Index (OI) and Production Index (PI) were accordingly obtained following procedures also described in Behar et al. (2001).

As described by Katz (1983), Rock-Eval pyrolysis can be effected by additional generation of $\mathrm{CO}_{2}$ derived from carbonate decomposition even at low temperatures. In order to investigate this effect on the present dataset, 6 samples with $2 \mathrm{~g}$ each were decarbonized using $30 \mathrm{~mL}$ 
of hydrochloric acid $(10 \%)$ at $80{ }^{\circ} \mathrm{C}$ for 30 min and subsequent neutralizing with distilled water. After settling of the $\mathrm{OM}$ overnight and decantation and evaporation at $50{ }^{\circ} \mathrm{C}$ of the remaining water, Rock-Eval pyrolysis was repeated on these samples.

\subsection{Organic petrographic analysis}

Eight samples were selected for organic petrology analysis based on their age and TOC content (0.52-9.33 wt.\%) to compare geochemical results with visual investigations like maceral qualification and vitrinite reflectance measurements as a reliable thermal maturity indicator. Thick sections were prepared by embedding sample pieces in a mixture of Araldite XW396 (epoxy resin) and Araldite XW397 (hardener) at a ratio of 10:3 and cutting them perpendicular to the bedding following the preparation procedure described in Sachse et al. (2012). The polished surfaces were analyzed in a dark room with a Zeiss Axio Imager microscope equipped with a tungsten-halogen lamp (12 V, $100 \mathrm{~W})$ for incident white light and a mercury lamp (HXP R120W/45C) for ultraviolet/violet light-excitation of fluorescence. An Epiplan-Neofluar 50x/0.85 oil immersion objective, oil with a refractive index of 1.518 , and the calibration standard Klein and Becker Leuco-Saphire $(0.592 \%)$ were used. Samples were qualitatively analyzed with respect to content of inertinite, vitrinite, liptinite (lamalginite and telalginite), pyrite and fossils (foraminifera, fish bones, shell fragments). Maceral identification was mainly based on their difference in reflectivity as well as their fluorescence intensity following procedures described by Littke (1993). Six samples were analyzed for random vitrinite reflectance $\left(\% \mathrm{VR}_{\mathrm{r}}\right)$. Measurements were processed with the software DISKUS Fossil, v.460.810 (Technisches Büro C. Hilgers, Königswinter, Germany). Details of the microscopical procedure are also described in Sachse et al. (2012).

The maximum paleotemperature $\left(T_{\text {peak }}\right)$ that was experienced during burial related heating was calculated according to Barker and Pawlewicz (1994):

$$
T_{\text {peak }}=\frac{\ln \left(\% \mathrm{VR}_{\mathrm{r}}+1.68\right)}{0.0124}
$$

\subsection{Molecular geochemistry}

Biomarkers can reveal information about specific organic precursor molecules which can help to identify original organic compounds. Further, the chirality of molecules (e.g. steranes) change with increasing temperature and, therefore, can be used as a thermal maturity indicator (Peters et al., 2005). Twelve samples were selected for molecular geochemical analysis by both, Gas Chromatography (GC) coupled with a Flame Ionization Detector (GC-FID) and GC coupled with a Mass Spectrometer (GC-MS). Prior to the analysis, maltene fractions were obtained using a DIONEX ASE 150 instrument (Thermo Scientific), which allows a full automatic extraction. Approximately $8 \mathrm{~g}$ of powdered rock sample were extracted by $40 \mathrm{~mL}$ of dichloromethane (DCM) in a high pressure cell at $100{ }^{\circ} \mathrm{C}$ and 100 bar during $14 \mathrm{~min}$. All maltene extracts were separated into three fractions by means of silica-gel based liquid column chromatography and eluents of different polarity: $5 \mathrm{~mL}$ pentane for the aliphatic fraction, $5 \mathrm{~mL}$ pentane/DCM (40:60) for the aromatic fraction, and $5 \mathrm{~mL}$ methanol for the polar fraction.

\subsubsection{GC-FID}

A Carlo Erba Strumentazione HRGC 5300 gas chromatograph equipped with a flame ionization detector was used to investigate the molecular composition of aliphatic fractions. The initial temperature was set to $80{ }^{\circ} \mathrm{C}$, kept for $3 \mathrm{~min}$, followed by heating at $5.0^{\circ} \mathrm{C} / \mathrm{min}$ up to $300{ }^{\circ} \mathrm{C}$, and held for $20 \mathrm{~min}$. The injection was performed in splitless mode set to $60 \mathrm{~s}$. Compound separation was performed in a $30 \mathrm{~m}$ long Zebron ZB-1 capillary column using hydrogen as carrier gas. The obtained chromatograms were interpreted using the Atlas $C D S$ software. Based on the relative abundance of the respective $n$-alkanes, the Terrigenous/Aquatic Ratio (TAR; Bourbonniere and Meyers, 1996), the odd-to-even predominance (OEP; Scalan and Smith, 1970) as well as the carbon preference index (CPI; Bray and Evans, 1961) were calculated as follow:

$$
\begin{gathered}
\text { TAR }=\frac{\left(n \mathrm{C}_{27}+n \mathrm{C}_{29}+n \mathrm{C}_{31}\right)}{\left(n \mathrm{C}_{15}+n \mathrm{C}_{17}+n \mathrm{C}_{19}\right)} \\
\mathrm{OEP}=\frac{\left(n \mathrm{C}_{21}+6 \times n \mathrm{C}_{23}+n \mathrm{C}_{25}\right)}{\left(4 \times n \mathrm{C}_{22}+4 \times n \mathrm{C}_{24}\right)} \\
\mathrm{CPI}=\frac{2 \times\left(n \mathrm{C}_{23}+n \mathrm{C}_{25}+n \mathrm{C}_{27}+n \mathrm{C}_{29}\right)}{\left(n \mathrm{C}_{22}+2 \times\left(n \mathrm{C}_{24}+n \mathrm{C}_{26}+n \mathrm{C}_{28}\right)+n \mathrm{C}_{30}\right)}
\end{gathered}
$$

\subsubsection{GC-MS}

Gas Chromatography was performed using a Mega Series HRGC 5160 gas chromatograph (Carlo Erba, IT) equipped with a $30 \mathrm{~m} \times 0.25 \mathrm{~mm} \times 0.25 \mu \mathrm{m}$ film Zebron ZB-5_MS fused silica capillary column. For specific detection a quadrupol mass spectrometer Trace MS (Thermoquest) was used. $1 \mu \mathrm{L}$ of sample was injected by split injection at $80{ }^{\circ} \mathrm{C}$. After $3 \mathrm{~min}$ isothermal hold, temperature was first increased by $10^{\circ} \mathrm{C} / \mathrm{min}$ up to $160{ }^{\circ} \mathrm{C}$, followed by a further temperature increase by $3{ }^{\circ} \mathrm{C} / \min$ up to $320^{\circ} \mathrm{C}$, which was held for $20 \mathrm{~min}$. Helium was used as carrier gas with a velocity of $30 \mathrm{~cm} / \mathrm{s}$. Hydrocarbons were detected by single ion mode $(\mathrm{EI}+, 70 \mathrm{eV}$, measured $m / z=191,205,217$, $218,259,372,386,400,412)$ with a source temperature of $200{ }^{\circ} \mathrm{C}$.

The identification of hopanes and steranes is based on a CHIRON reference standard (Hopane/Sterane Calibration Mix) and by comparison with other reference material. For peak quantification the Xcalibur software (Thermo Finnigan) was used. The identified peaks for both hopanes and steranes used in this work for calculated ratios and their respective measured $m / z$ ratios are listed in Table 2 .

The ratio of steranes to hopanes was calculated according to Peters et al. (2005) by the ratio of $\mathrm{C}_{27}-\mathrm{C}_{29}$ regular steranes to $\mathrm{C}_{29}-\mathrm{C}_{30} 17 \alpha$ hopanes. 
Table 2. Identified hopane and sterane peaks used in this work.

\begin{tabular}{|c|c|c|c|}
\hline Peak ID & Hopane $\mathrm{m} / \mathrm{z}=191$ & Peak ID & Sterane $\mathrm{m} / \mathrm{z}=217$ \\
\hline A & $\mathrm{C} 25$ trycyclic terpane $(22 \mathrm{~S}+\mathrm{R})$ & $\mathrm{a}$ & C27 pa-diacholestane (20S) \\
\hline B & C26 tricyclic terpane $(22 \mathrm{~S})$ & $\mathrm{b}$ & C27 pa-diacholestane (20R) \\
\hline $\mathrm{C}$ & $\mathrm{C} 26$ tricyclic terpane $(22 \mathrm{R})$ & $\mathrm{c}$ & C28 pa-diasterane a (20S) \\
\hline $\mathrm{D}$ & Ts $18 \mathrm{a}(\mathrm{H})$-trisnorhopane & $\mathrm{d}$ & C28 pa-diasterane b (20S) \\
\hline $\mathrm{E}$ & Tm 17a $(\mathrm{H})$-trisnorhopane & e & C28 pa-diasterane a (20R) \\
\hline $\mathrm{F}$ & C29 Tm 17a(H)21p(H)-norhopane & $\mathrm{f}$ & C28 pa-diasterane b (20R) \\
\hline G & $\mathrm{C} 29$ Ts $18 \mathrm{a}(\mathrm{H})$-norneohopane & $\mathrm{g}$ & C27 aa-cholestane (20S) \\
\hline $\mathrm{H}$ & C30 17a(H)-hopane & $\mathrm{h}$ & C27 pp-cholestane (20R) \\
\hline I & C30 moretane & $\mathrm{i}$ & C27 pp-cholestane (20S) \\
\hline $\mathrm{J}$ & C31 17a(H)-homohopane (22S) & $\mathrm{j}$ & C27 aa-cholestane (20R) \\
\hline K & C31 17a(H)-homohopane (22R) & $\mathrm{k}$ & C28 aa-ergostane (20S) \\
\hline $\mathrm{L}$ & C32 17a (H), 2ip (H)-30,31 -bishomohopane (22S) & 1 & C28 pp-ergostane (20R) \\
\hline \multirow[t]{6}{*}{$\mathrm{M}$} & C32 17a (H), 21 p (H)-30,31 -bishomohopane (22R) & $\mathrm{m}$ & C28 pp-ergostane (20S) \\
\hline & & $\mathrm{n}$ & C28 aa-ergostane (20R) \\
\hline & & o & C29 aa-stigmastane (20S) \\
\hline & & $\mathrm{p}$ & C29 pp-stigmastane (20R) \\
\hline & & q & C29 pp-stigmastane (20S) \\
\hline & & $\mathrm{r}$ & C29 aa-stigmastane (20R) \\
\hline
\end{tabular}

\section{Results}

\subsection{Elemental analysis and Rock-Eval pyrolysis}

Results of the elemental analysis are shown in Figure 3 and listed in Table 3. TOC contents of the investigated samples range from 0.1 to $9.3 \mathrm{wt} . \%$ with an average of $0.83 \mathrm{wt} . \%$ with exception of Santonian and Campanian to Maastrichtian samples, where the TOC contents are consistently low, close to the average of $0.25 \mathrm{wt} . \%$. The highest TOC contents are observed in samples of Bartonian to Priabonian age with an average of 4.8 wt. $\%$.

TIC contents range from 1.4 to 11.9 wt.\% with an average of $10.3 \mathrm{wt} . \%$. Calculated carbonate contents show a weak negative correlation with TOC content (Fig. 3). Turonian to Santonian samples are (almost) pure carbonates. Some of these rocks contain dolomite rather than calcite; therefore, calculated $\mathrm{CaCO}_{3}$ contents partly exceed $100 \%$. Ypresian to Bartonian samples contain significant amounts of dolomite rhombs. Therefore, the carbonate content of these intervals was calculated assuming that the TIC content is mainly derived from dolomite.

TS values range from 0.03 to 1.16 wt.\% with an average of 0.3 wt.\%. TS correlates positively with TOC (Fig. 3). $\mathrm{TS} / \mathrm{TOC}$ ratios are low to moderate ranging from 0.01 to 3.66 .

Rock-Eval results are shown in Figure 3 and listed in Table 3. Rock-Eval analysis revealed no meaningful results for the three Messinian, two Eocene to Miocene, and some Campanian and Santonian samples, probably due to oxidation of OM. The remaining 104 samples are marked by low $\mathrm{S} 1$ (0.00-0.77 $\mathrm{mg} \mathrm{HC} / \mathrm{g}$ rock), but intermediate $\mathrm{S} 2$ values (0.08-49.70 mg HC/g rock). Both parameters correlate pos- itively with each other and also with their respective TOC content (Fig. 3). S3 values are low with only $0.47-5.36 \mathrm{mg}$ $\mathrm{CO}_{2} / \mathrm{g}$ rock. $T_{\max }$ values range from $412{ }^{\circ} \mathrm{C}$ to $434{ }^{\circ} \mathrm{C}$.

HI values are relatively high, but vary strongly from 45 to $580 \mathrm{mg} \mathrm{HC} / \mathrm{g}$ TOC with an average of $240 \mathrm{mg} \mathrm{HC} / \mathrm{g}$ TOC. OI values vary from 20 to $833 \mathrm{mg} \mathrm{CO} / \mathrm{g}$ TOC with an average of $152 \mathrm{mg} \mathrm{CO} / \mathrm{g}$ TOC. Some extremely high OI values are probably caused by oxygen release from thermally instable carbonates (Katz, 1983). OI values correlate negatively with HI values. PI values are very low at 0.01-0.12. The two solid bitumen-impregnated samples do not show any significant difference, since the amount of solid bitumen compared to the whole bulk rock volume is very low.

The results of the $\mathrm{HCl}$-treated samples are shown in Table 4 . OI values decrease by a factor between 0.8 and 0.2 , while $\mathrm{HI}$ values increase by a factor of $1.2-3.5$ as compared to the bulk rock samples. The strongest mineral matrix effect is observed for samples with low TOC contents.

\subsection{Petrographic analysis}

Most samples, except the two solid bitumen-impregnated samples $(15 / 891,15 / 896)$, contain different macerals in varying amounts (Tab. 5). Vitrinite and inertinite particles occur rarely, are small-sized and often have highly structured surfaces (Figs. 4A and 4B) which hampered random vitrinite reflectance measurements. In contrast, liptinite (lamalginite and telalginite) is very abundant, varies in size and shows yellow-golden fluorescence after ultravioletviolet light excitation (Figs. 4A and 4B, red arrows). The highest contribution of $\mathrm{OM}$ is made up of submicroscopic 

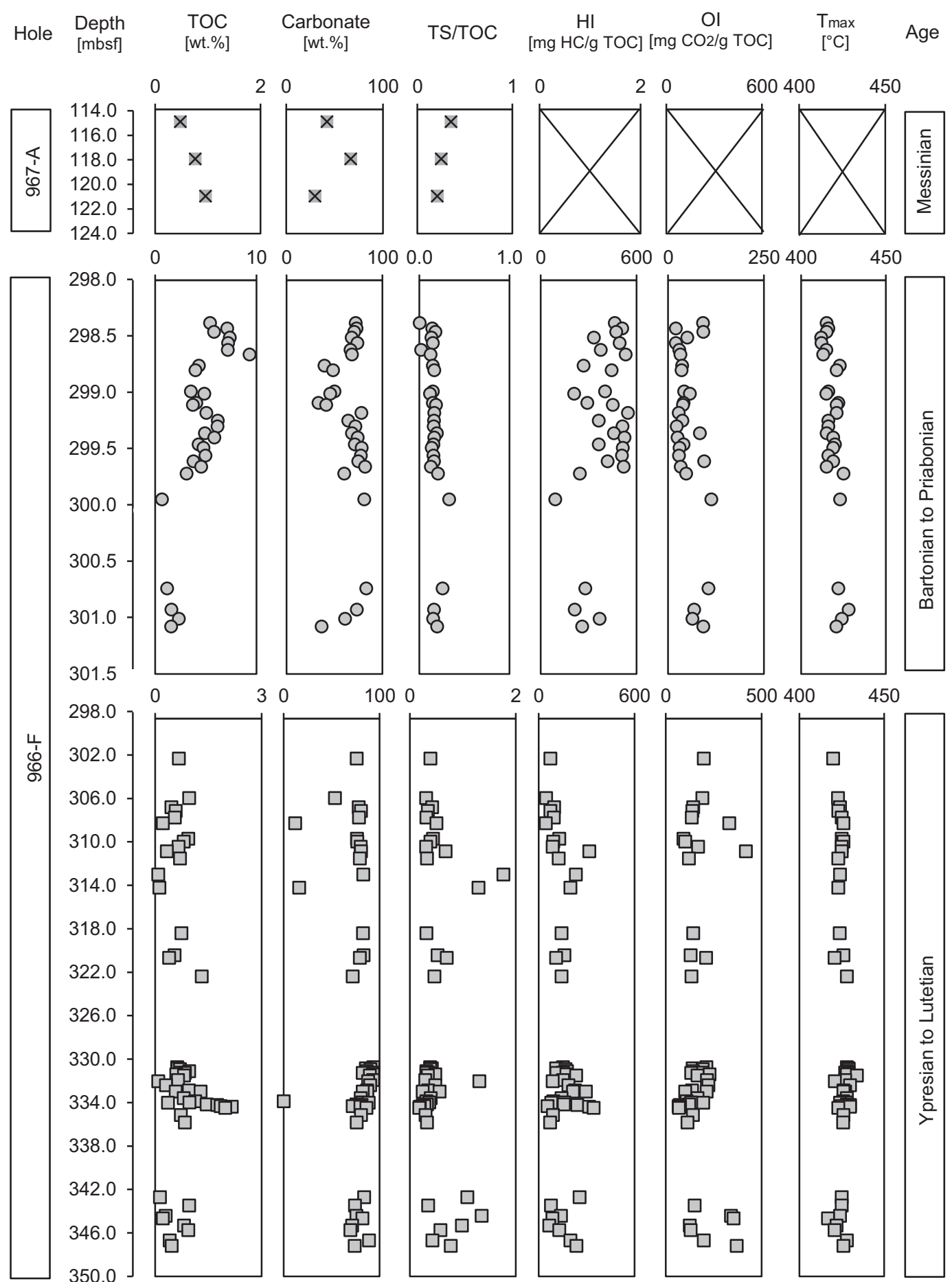

Fig. 3. Elemental analysis and Rock-Eval results of ODP Leg 160 core samples that originate from the Eratosthenes Seamount (ESM), southern offshore area of Cyprus. Note that scales vary in the different intervals. Big crosses mark intervals where no results were obtained.

amorphous liptinites (Figs. 4A and 4B). Pyrite grain size is small and usually occurs in framboidal shape, but almost all samples also contain minor amounts of small, euhedral pyrite (Fig. 4C). Foraminifera, fish bones and/or shell fragments occur in all samples and are rather common
(Tab. 5). Foraminifera often show recrystallization and blocky cement reduces the intraparticle porosity (classification after Choquette and Pray, 1970). Foraminifera abundance seems to correlate negatively with the $\mathrm{OM}$ content and pyrite (Tab. 5). Dolomite rhombs are very rare to 


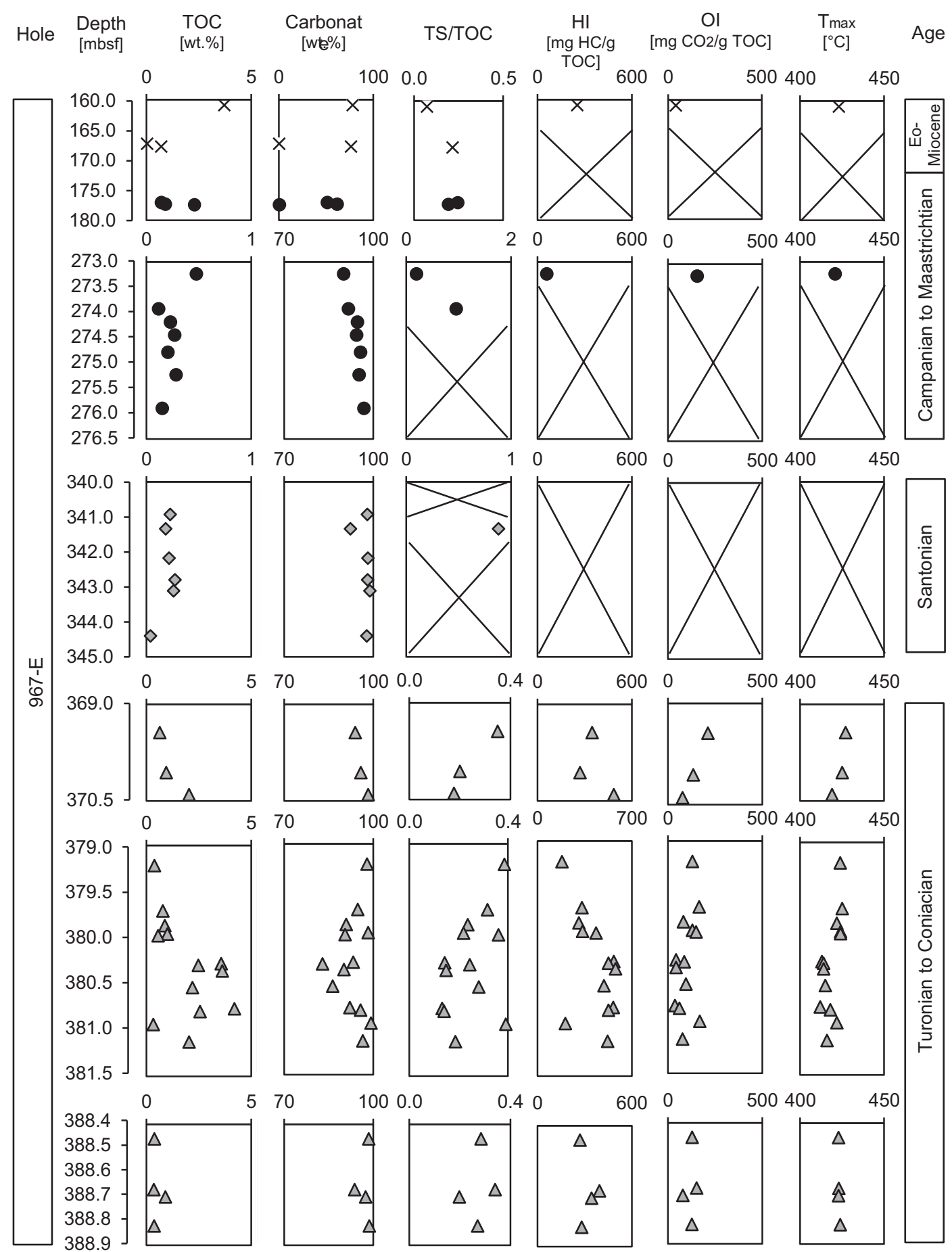

Fig. 3. Continued.

absent in the Upper Cretaceous samples and abundant in the Eocene samples (Fig. 4B).

The solid bitumen-impregnated samples do not contain any vitrinite or inertinite and almost no liptinite. Here, foraminifera are abundant. Solid bitumen occurs as accumulation in cavities and with locally large framboidal pyrite in its close vicinity (Fig. 4D).
For six samples the vitrinite reflectance could be measured (Tab. 6). However, in only four samples more than 20 vitrinite particles could be measured to generate reliable results (see Barker and Pawlewicz, 1993) (Tab. 6). Measured $\mathrm{VR}_{\mathrm{r}}$ ranges from $0.25 \%$ to $0.3 \%$. Counts and mean values of vitrinite reflectance are listed in Table. 6. 
Table 3. Results of the elemental analysis and Rock-Eval pyrolysis. TOC $=$ Total Organic Carbon; TIC $=$ Total Inorganic Carbon; TS = Total Sulfur; $T_{\max }=$ temperature at the peak of S2; HI $=$ Hydrogen Index $(\mathrm{S} 2 / \mathrm{TOC} \times 100)$; $\mathrm{OI}=$ Oxygen Index $(\mathrm{S} 3 / \mathrm{TOC} \times 100) ;[-]:$ not determined.

\begin{tabular}{|c|c|c|c|c|c|c|c|c|c|}
\hline Sample & TOC [wt.\%] & TIC [wt.\%] & TS [wt.\%] & $\begin{array}{c}\mathrm{S} 1[\mathrm{mg} \\
\mathrm{HC} / \mathrm{g} \\
\mathrm{rock}] \\
\end{array}$ & $\begin{array}{c}\mathrm{S} 2[\mathrm{mg} \\
\mathrm{HC} / \mathrm{g} \\
\mathrm{rock}]\end{array}$ & $\begin{array}{l}\mathrm{S} 3[\mathrm{mg} \\
\mathrm{CO}_{2} / \mathrm{g} \\
\text { rock] } \\
\end{array}$ & $\operatorname{Tmax}\left[{ }^{\circ} \mathrm{C}\right]$ & $\begin{array}{c}\mathrm{Hl}[\mathrm{mg} \\
\mathrm{HC} / \mathrm{g} \\
\mathrm{TOC}] \\
\end{array}$ & $\begin{array}{l}\mathrm{Ol}[\mathrm{mg} \\
\mathrm{CO}_{2} / \mathrm{g} \\
\mathrm{TOC}] \\
\end{array}$ \\
\hline $15 / 892$ & 0.48 & 5.07 & 0.17 & 0.02 & 0.12 & 1.31 & 260 & 25 & 273 \\
\hline $15 / 893$ & 0.76 & 8.02 & 0.19 & 0.02 & 0.17 & 1.32 & 260 & 22 & 174 \\
\hline $15 / 894$ & 0.96 & 3.55 & 0.2 & 0.02 & 0.20 & 1.29 & 391 & 21 & 134 \\
\hline $17 / 1679$ & 5.43 & 9.20 & 0.03 & 0.77 & 25.23 & 4.94 & 415 & 465 & 91 \\
\hline $15 / 863$ & 7.12 & 9.32 & 1.04 & 0.63 & 36.35 & 1.46 & 416 & 511 & 21 \\
\hline $17 / 1680$ & 5.84 & 8.99 & 1.05 & 0.72 & 27.67 & 5.36 & 415 & 474 & 92 \\
\hline $17 / 1681$ & 7.39 & 8.65 & 0.99 & 0.33 & 24.69 & 3.69 & 412 & 334 & 50 \\
\hline $15 / 864$ & 7.23 & 9.42 & 1.09 & 0.39 & 35.74 & 1.47 & 412 & 494 & 20 \\
\hline $17 / 1682$ & 7.19 & 8.51 & 0.15 & 0.32 & 27.02 & 2.11 & 415 & 376 & 29 \\
\hline $15 / 865$ & 9.33 & 8.68 & 1.16 & 0.68 & 49.70 & 3.00 & 413 & 533 & 32 \\
\hline $17 / 1683$ & 4.34 & 5.05 & 0.66 & 0.30 & 11.68 & 1.60 & 423 & 269 & 37 \\
\hline $15 / 866$ & 3.99 & 6.20 & 0.67 & 0.31 & 17.72 & 1.42 & 421 & 444 & 36 \\
\hline $15 / 867$ & 3.55 & 6.37 & 0.54 & 0.18 & 14.29 & 1.48 & 416 & 403 & 42 \\
\hline $17 / 1685$ & 4.88 & 5.79 & 0.58 & 0.16 & 10.24 & 2.77 & 415 & 210 & 57 \\
\hline $17 / 1686$ & 4.07 & 4.24 & 0.62 & 0.20 & 11.87 & 1.66 & 422 & 292 & 41 \\
\hline $15 / 868$ & 3.73 & 5.25 & 0.69 & 0.16 & 16.87 & 1.45 & 421 & 452 & 39 \\
\hline $15 / 869$ & 5.08 & 9.97 & 0.84 & 0.18 & 27.79 & 1.43 & 421 & 547 & 28 \\
\hline $17 / 1687$ & 6.20 & 8.22 & 1.01 & 0.19 & 22.52 & 2.31 & 416 & 363 & 37 \\
\hline $15 / 870$ & 6.16 & 9.16 & 0.98 & 0.24 & 31.60 & 1.40 & 416 & 513 & 23 \\
\hline $17 / 1688$ & 4.92 & 8.69 & 0.95 & 0.28 & 22.56 & 4.08 & 415 & 459 & 83 \\
\hline $15 / 871$ & 5.85 & 9.44 & 0.98 & 0.22 & 30.68 & 1.45 & 419 & 524 & 25 \\
\hline $17 / 1689$ & 4.31 & 9.09 & 0.68 & 0.17 & 15.69 & 1.74 & 420 & 364 & 40 \\
\hline $15 / 872$ & 4.80 & 10.00 & 0.66 & 0.17 & 24.73 & 1.43 & 419 & 515 & 30 \\
\hline $15 / 873$ & 4.99 & 9.89 & 0.78 & 0.17 & 25.43 & 1.43 & 416 & 510 & 29 \\
\hline $17 / 1690$ & 3.80 & 9.52 & 0.63 & 0.17 & 15.94 & 3.57 & 419 & 419 & 94 \\
\hline $15 / 874$ & 4.57 & 10.45 & 0.59 & 0.27 & 23.77 & 1.51 & 415 & 520 & 33 \\
\hline $17 / 1691$ & 3.13 & 7.65 & 0.65 & 0.22 & 7.67 & 1.47 & 425 & 245 & 47 \\
\hline $17 / 1692$ & 0.70 & 10.32 & 0.23 & 0.06 & 0.64 & 0.79 & 423 & 91 & 112 \\
\hline $15 / 875$ & 1.19 & 10.61 & 0.31 & 0.07 & 3.33 & 1.25 & 422 & 280 & 105 \\
\hline $17 / 1693$ & 1.63 & 9.34 & 0.27 & 0.08 & 3.49 & 1.11 & 428 & 214 & 68 \\
\hline $15 / 876$ & 2.35 & 7.79 & 0.36 & 0.15 & 8.70 & 1.50 & 424 & 370 & 64 \\
\hline $17 / 1694$ & 1.58 & 4.65 & 0.31 & 0.11 & 4.12 & 1.45 & 421 & 261 & 92 \\
\hline $15 / 877$ & 0.67 & 9.71 & 0.26 & 0.04 & 0.49 & 1.33 & 420 & 73 & 199 \\
\hline $17 / 1696$ & 0.96 & 6.81 & 0.30 & 0.04 & 0.45 & 1.84 & 423 & 46 & 192 \\
\hline $17 / 1698$ & 0.46 & 10.00 & 0.20 & 0.03 & 0.45 & 0.66 & 424 & 97 & 143 \\
\hline $17 / 1699$ & 0.58 & 10.28 & 0.20 & 0.03 & 0.43 & 0.80 & 423 & 74 & 139 \\
\hline $17 / 1700$ & 0.56 & 10.04 & 0.17 & 0.03 & 0.54 & 0.77 & 425 & 96 & 137 \\
\hline $17 / 1701$ & 0.22 & 1.52 & 0.11 & 0.00 & 0.10 & 0.74 & 426 & 45 & 332 \\
\hline $17 / 1702$ & 0.94 & 9.78 & 0.41 & 0.03 & 1.22 & 0.87 & 425 & 129 & 93 \\
\hline $17 / 1703$ & 0.81 & 9.80 & 0.32 & 0.04 & 0.75 & 0.82 & 426 & 92 & 101 \\
\hline $17 / 1704$ & 0.66 & 10.25 & 0.20 & 0.04 & 0.58 & 1.12 & 425 & 88 & 170 \\
\hline $17 / 1705$ & 0.33 & 10.30 & 0.22 & 0.00 & 1.05 & 1.38 & 425 & 318 & 418 \\
\hline $17 / 1706$ & 0.70 & 10.14 & 0.23 & 0.04 & 0.88 & 0.85 & 423 & 125 & 121 \\
\hline $17 / 1707$ & 0.09 & 10.61 & 0.16 & 0.00 & 0.21 & 0.75 & 424 & 233 & 833 \\
\hline
\end{tabular}


Table 3. (continued).

\begin{tabular}{|c|c|c|c|c|c|c|c|c|c|}
\hline Sample & TOC [wt.\%] & TIC [wt.\%] & TS [wt.\%] & $\begin{array}{c}\mathrm{S} 1[\mathrm{mg} \\
\mathrm{HC} / \mathrm{g} \\
\mathrm{rock}]\end{array}$ & $\begin{array}{c}\mathrm{S} 2[\mathrm{mg} \\
\mathrm{HC} / \mathrm{g} \\
\mathrm{rock}]\end{array}$ & $\begin{array}{c}\mathrm{S} 3[\mathrm{mg} \\
\mathrm{C}_{2} / \mathrm{g} \\
\text { rock] }\end{array}$ & $\operatorname{Tmax}\left[{ }^{\circ} \mathrm{C}\right]$ & $\begin{array}{c}\mathrm{Hl}[\mathrm{mg} \\
\mathrm{HC} / \mathrm{g} \\
\mathrm{TOC}]\end{array}$ & $\begin{array}{c}\mathrm{Ol}[\mathrm{mg} \\
\mathrm{CO}_{2} / \mathrm{g} \\
\mathrm{TOC}]\end{array}$ \\
\hline $17 / 1708$ & 0.12 & 2.05 & 0.16 & 0.01 & 0.24 & 0.94 & 423 & 200 & 783 \\
\hline $17 / 1709$ & 0.75 & 10.58 & 0.24 & 0.05 & 1.07 & 1.08 & 424 & 143 & 144 \\
\hline $17 / 1711$ & 0.55 & 10.63 & 0.29 & 0.05 & 0.89 & 0.71 & 426 & 161 & 130 \\
\hline $17 / 1712$ & 0.40 & 10.14 & 0.28 & 0.04 & 0.44 & 0.84 & 421 & 110 & 211 \\
\hline $17 / 1715$ & 1.32 & 9.21 & 0.61 & 0.03 & 1.89 & 1.78 & 428 & 143 & 135 \\
\hline $15 / 878$ & 0.62 & 11.94 & 0.24 & 0.03 & 0.95 & 1.32 & 428 & 153 & 213 \\
\hline $17 / 1717$ & 0.64 & 10.95 & 0.27 & 0.07 & 0.71 & 0.90 & 429 & 429 & 111 \\
\hline $15 / 879$ & 0.70 & 11.55 & 0.27 & 0.04 & 1.18 & 1.35 & 429 & 429 & 169 \\
\hline $15 / 880$ & 0.96 & 11.06 & 0.30 & 0.05 & 1.71 & 1.36 & 428 & 428 & 178 \\
\hline $15 / 881$ & 0.71 & 11.78 & 0.25 & 0.04 & 1.09 & 1.37 & 427 & 427 & 154 \\
\hline $17 / 1718$ & 0.84 & 10.54 & 0.26 & 0.11 & 0.94 & 1.12 & 429 & 429 & 112 \\
\hline $15 / 882$ & 0.60 & 11.88 & 0.29 & 0.03 & 1.04 & 1.37 & 428 & 428 & 173 \\
\hline $15 / 883$ & 0.82 & 11.48 & 0.28 & 0.04 & 1.93 & 1.36 & 434 & 434 & 235 \\
\hline $15 / 884$ & 0.65 & 11.91 & 0.19 & 0.03 & 0.99 & 1.40 & 427 & 427 & 152 \\
\hline $17 / 1720$ & 0.09 & 11.25 & 0.12 & 0.00 & 0.08 & 0.97 & 421 & 421 & 89 \\
\hline $17 / 1721$ & 0.31 & 11.53 & 0.15 & 0.06 & 0.58 & 0.69 & 430 & 430 & 187 \\
\hline $15 / 885$ & 0.95 & 11.11 & 0.33 & 0.04 & 2.17 & 1.31 & 426 & 426 & 228 \\
\hline $15 / 886$ & 1.28 & 11.12 & 0.31 & 0.04 & 2.76 & 1.31 & 427 & 427 & 216 \\
\hline $17 / 1722$ & 0.58 & 10.52 & 0.33 & 0.01 & 1.72 & 1.24 & 426 & 426 & 297 \\
\hline $15 / 887$ & 0.81 & 10.26 & 0.32 & 0.03 & 1.16 & 1.35 & 428 & 428 & 143 \\
\hline $17 / 1724$ & 1.13 & 0.01 & 0.36 & 0.04 & 1.03 & 1.25 & 426 & 426 & 91 \\
\hline $15 / 888$ & 0.97 & 10.43 & 0.36 & 0.04 & 1.56 & 1.29 & 428 & 428 & 161 \\
\hline $17 / 1726$ & 1.45 & 9.67 & 0.47 & 0.03 & 2.29 & 1.79 & 428 & 429 & 111 \\
\hline $15 / 889$ & 1.75 & 10.39 & 0.43 & 0.06 & 4.25 & 1.30 & 430 & 429 & 169 \\
\hline $17 / 1727$ & 1.85 & 9.17 & 0.51 & 0.04 & 1.03 & 1.25 & 425 & 428 & 178 \\
\hline $15 / 890$ & 2.16 & 10.21 & 0.41 & 0.09 & 6.82 & 1.63 & 430 & 427 & 154 \\
\hline $15 / 891$ & 1.98 & 11.03 & 0.36 & 0.11 & 6.81 & 1.36 & 423 & 429 & 112 \\
\hline $17 / 1729$ & 0.73 & 10.28 & 0.22 & 0.04 & 0.65 & 1.03 & 426 & 428 & 173 \\
\hline $17 / 1732$ & 0.84 & 9.73 & 0.28 & 0.04 & 0.60 & 0.96 & 426 & 434 & 235 \\
\hline $17 / 1733$ & 0.14 & 10.71 & 0.15 & 0.02 & 0.36 & 0.79 & 425 & 427 & 152 \\
\hline $17 / 1735$ & 0.96 & 9.50 & 0.34 & 0.04 & 0.75 & 1.45 & 425 & 421 & 89 \\
\hline $17 / 1736$ & 0.30 & 9.69 & 0.41 & 0.00 & 0.42 & 1.02 & 424 & 430 & 187 \\
\hline $17 / 1737$ & 0.22 & 10.50 & 0.81 & 0.01 & 0.19 & 0.78 & 417 & 426 & 228 \\
\hline $17 / 1738$ & 0.82 & 9.10 & 0.81 & 0.04 & 0.55 & 1.03 & 422 & 427 & 216 \\
\hline $17 / 1740$ & 0.94 & 8.90 & 0.55 & 0.09 & 0.68 & 1.22 & 421 & 426 & 297 \\
\hline $17 / 1742$ & 0.41 & 11.35 & 0.18 & 0.04 & 0.49 & 0.81 & 428 & 428 & 143 \\
\hline $17 / 1743$ & 0.47 & 9.45 & 0.36 & 0.03 & 1.11 & 1.74 & 426 & 426 & 91 \\
\hline $15 / 895$ & 3.72 & 9.40 & 0.27 & 0.07 & 9.41 & 1.54 & 423 & 428 & 161 \\
\hline $17 / 1744$ & 0.03 & 0.06 & - & - & - & - & - & - & - \\
\hline $17 / 1745$ & 0.70 & 9.19 & 0.18 & - & - & - & - & - & - \\
\hline $17 / 1746$ & 0.71 & 6.16 & 0.17 & - & - & - & - & - & - \\
\hline $17 / 1747$ & 0.91 & 7.41 & 0.17 & - & - & - & - & - & - \\
\hline $17 / 1748$ & 2.29 & 0.06 & 0.42 & - & - & - & - & - & - \\
\hline $15 / 896$ & 0.52 & 11.91 & 0.19 & 0.03 & 0.44 & 1.30 & 426 & 426 & 85 \\
\hline $17 / 1749$ & 0.48 & 10.81 & 0.19 & 0.03 & 0.44 & 1.30 & 426 & 421 & 59 \\
\hline $17 / 1751$ & 0.12 & 11.00 & 0.11 & - & - & - & - & - & - \\
\hline
\end{tabular}


Table 3. (continued).

\begin{tabular}{|c|c|c|c|c|c|c|c|c|c|}
\hline Sample & TOC [wt.\%] & TIC [wt.\%] & TS [wt.\%] & $\begin{array}{c}\mathrm{S} 1[\mathrm{mg} \\
\mathrm{HC} / \mathrm{g} \\
\text { rock] }\end{array}$ & $\begin{array}{c}\mathrm{S} 2[\mathrm{mg} \\
\mathrm{HC} / \mathrm{g} \\
\mathrm{rock}]\end{array}$ & $\begin{array}{c}\mathrm{S} 3[\mathrm{mg} \\
\mathrm{C}_{2} / \mathrm{g} \\
\text { rock] } \\
\end{array}$ & $\operatorname{Tmax}\left[{ }^{\circ} \mathrm{C}\right]$ & $\begin{array}{c}\mathrm{Hl}[\mathrm{mg} \\
\mathrm{HC} / \mathrm{g} \\
\mathrm{TOC}] \\
\end{array}$ & $\begin{array}{l}\mathrm{Ol}[\mathrm{mg} \\
\mathrm{C}_{2} / \mathrm{g} \\
\mathrm{TOC}] \\
\end{array}$ \\
\hline $17 / 1752$ & 0.23 & 11.37 & - & - & - & - & - & - & - \\
\hline $17 / 1753$ & 0.27 & 11.33 & - & - & - & - & - & - & - \\
\hline $17 / 1754$ & 0.20 & 11.50 & - & - & - & - & - & - & - \\
\hline $17 / 1755$ & 0.28 & 11.44 & - & - & - & - & - & - & - \\
\hline $17 / 1756$ & 0.15 & 11.63 & - & - & - & - & - & - & - \\
\hline $17 / 1757$ & 0.23 & 11.76 & - & - & - & - & - & - & - \\
\hline $17 / 1758$ & 0.18 & 11.08 & 0.16 & - & - & - & - & - & - \\
\hline $17 / 1759$ & 0.22 & 11.79 & - & - & - & - & - & - & - \\
\hline $17 / 1760$ & 0.27 & 11.77 & - & - & - & - & - & - & - \\
\hline $17 / 1761$ & 0.26 & 11.86 & - & - & - & - & - & - & - \\
\hline $17 / 1762$ & 0.04 & 12.49 & - & - & - & - & - & - & - \\
\hline $15 / 897$ & 0.63 & 12.15 & 0.22 & 0.04 & 2.19 & 1.34 & 427 & 427 & 348 \\
\hline $15 / 898$ & 0.95 & 12.24 & 0.19 & 0.06 & 2.57 & 1.28 & 425 & 425 & 271 \\
\hline $15 / 899$ & 2.04 & 11.80 & 0.36 & 0.18 & 9.91 & 1.58 & 419 & 419 & 486 \\
\hline $17 / 1763$ & 0.38 & 11.76 & 0.15 & 0.04 & 0.55 & 1.03 & 422 & 424 & 183 \\
\hline $15 / 900$ & 0.79 & 12.10 & 0.25 & 0.05 & 2.61 & 1.31 & 425 & 425 & 330 \\
\hline $17 / 1764$ & 0.88 & 10.91 & 0.21 & 0.08 & 2.71 & 0.72 & 421 & 421 & 308 \\
\hline $15 / 901$ & 1.00 & 12.55 & 0.22 & 0.06 & 3.36 & 1.30 & 424 & 424 & 336 \\
\hline $17 / 1765$ & 0.55 & 10.87 & 0.20 & 0.02 & 2.39 & 0.82 & 424 & 424 & 435 \\
\hline $15 / 902$ & 3.57 & 11.20 & 0.51 & 0.23 & 20.25 & 1.57 & 413 & 413 & 567 \\
\hline $17 / 1766$ & 2.48 & 9.96 & 0.61 & 0.16 & 13.08 & 2.16 & 414 & 414 & 527 \\
\hline $15 / 903$ & 3.62 & 10.82 & 0.54 & 0.19 & 20.98 & 1.57 & 414 & 414 & 580 \\
\hline $17 / 1767$ & 2.19 & 10.37 & 0.62 & 0.16 & 10.83 & 2.09 & 415 & 415 & 495 \\
\hline $15 / 904$ & 4.20 & 11.06 & 0.56 & 0.33 & 23.62 & 1.59 & 412 & 412 & 562 \\
\hline $15 / 905$ & 2.56 & 11.49 & 0.36 & 0.14 & 13.48 & 1.56 & 418 & 418 & 527 \\
\hline $17 / 1768$ & 0.32 & 11.91 & 0.13 & 0.05 & 0.67 & 0.54 & 422 & 422 & 208 \\
\hline $15 / 906$ & 2.04 & 11.58 & 0.38 & 0.11 & 10.61 & 1.58 & 416 & 416 & 520 \\
\hline $17 / 1769$ & 0.38 & 11.83 & 0.11 & 0.06 & 1.03 & 0.49 & 423 & 423 & 271 \\
\hline $17 / 1770$ & 0.36 & 11.25 & 0.12 & 0.02 & 1.42 & 0.55 & 423 & 423 & 394 \\
\hline $17 / 1771$ & 0.91 & 11.70 & 0.18 & 0.08 & 3.13 & 0.73 & 423 & 423 & 344 \\
\hline $17 / 1772$ & 0.37 & 11.85 & 0.10 & 0.05 & 1.04 & 0.47 & 424 & 424 & 283 \\
\hline
\end{tabular}

$T_{\text {peak }}$ derived from initial vitrinite reflectance measurements (Tab. 6) ranges from 20 to $39{ }^{\circ} \mathrm{C}$ for the vitrinitecontaining samples indicating that sediments have not reached much higher temperatures or burial depths than at present-day.

\subsection{Molecular organic geochemistry}

Based on the low thermal maturity as it is indicated by low vitrinite reflectance and Rock-Eval $T_{\max }$ values, only aliphatic hydrocarbon fractions were analyzed. Three types of aliphatic distributions were observed: (1) samples showing a clear predominance of medium-chain $n$-alkanes $\left(n-\mathrm{C}_{12}-n-\mathrm{C}_{20}\right)$ with almost no long-chain molecules
(Fig. 5A); (2) samples showing a predominance of mediumchain $n$-alkanes over abundant long-chain $n$-alkanes $(n$ $\left.\mathrm{C}_{20}-n-\mathrm{C}_{35}\right)$ that can even reach tendencies of bimodal distribution (e.g. 15/899; Fig. 5B); (3) two exceptions are samples $15 / 892$ and $15 / 888$ which are characterized by a skewed distribution over the full range of detected $n$-alkanes $\left(n-\mathrm{C}_{12}-n-\mathrm{C}_{35}\right)$, with a decreasing frequency of shorter/longer chain molecules, respectively. There is no clear correlation between stratigraphy and the type of $n$-alkanes distribution.

Calculated geochemical ratios are shown in Table. 7. Pristane $(\mathrm{Pr})$ /phytane $(\mathrm{Ph})$ ratios vary between 1.0 and 1.6 with the exception of one Messinian (15/892), one Bartonian to Priabonian (15/868) and one Ypresian to Lutetian $(15 / 888)$ sample with ratios of $0.50,0.49$ and 
Table 4. Comparison of bulk rock and HCl-treated samples. TOC $=$ Total Organic Carbon; TIC $=$ Total Inorganic Carbon; HI $=$ Hydrogen Index $(\mathrm{S} 2 / \mathrm{TOC} \times 100) ; \mathrm{OI}=$ Oxygen Index $(\mathrm{S} 3 / \mathrm{TOC} \times 100)$.

\begin{tabular}{llcccc}
\hline Sample & \multicolumn{1}{c}{ Age } & TOC [wt.\%] & TIC [wt.\%] & HI $[\mathrm{mg}$ HC $/ \mathrm{g}$ TOC] & OI $\left[\mathrm{mg} \mathrm{CO}_{2} / \mathrm{g}^{\mathrm{TOC}}\right]$ \\
\hline 106 & Bartonian to Priabonian & 7.39 & 8.65 & 334 & 50 \\
$106-\mathrm{HCl}$ & Bartonian to Priabonian & 31.96 & 0.12 & 568 & 40 \\
110 & Bartonian to Priabonian & 4.88 & 5.79 & 210 & 57 \\
$110-\mathrm{HCL}$ & Bartonian to Priabonian & 9.52 & 0.04 & 407 & 39 \\
121 & Ypresian to Lutetian & 0.96 & 6.81 & 46 & 192 \\
$121-\mathrm{HCl}$ & Ypresian to Lutetian & 2.31 & 0.01 & 159 & 50 \\
137 & Ypresian to Lutetian & 0.4 & 10.14 & 110 & 211 \\
$137-\mathrm{HCl}$ & Ypresian to Lutetian & 2.7 & 0.02 & 252 & 50 \\
188 & Turonian to Coniacian & 0.3 & 11.74 & 348 & 213 \\
$188-\mathrm{HCl}$ & Turonian to Coniacian & 5.1 & 0.03 & 432 & 36 \\
192 & Turonian to Coniacian & 2.19 & 10.37 & 495 & 95 \\
$192-\mathrm{HCl}$ & Turonian to Coniacian & 23.54 & 0.09 & 592 & 33 \\
\hline
\end{tabular}

Table 5. Results from microscopic analysis: Qualitative amounts of analyzed feature $(\mathrm{OM}=$ total observable organic matter; $\mathrm{V}=$ vitrinite; $\mathrm{I}=$ inertinite; $\mathrm{L}=$ liptinite; Foram = foraminifera; Py = pyrite; Dolo = dolomite) decrease from +++ to $+;-$ indicates that the feature occurs only rarely or not at all.

\begin{tabular}{llccccccc}
\hline Sample & \multicolumn{1}{c}{ Age } & OM & V & I & L & Foram & Py & Dolo \\
\hline $15 / 865$ & Bartonian to Priabonian & +++ & ++ & - & ++ & + & ++ & - \\
$15 / 871$ & Bartonian to Priabonian & +++ & ++ & - & ++ & + & ++ & +++ \\
$15 / 886$ & Ypresian to Lutetian & ++ & + & - & + & ++ & +++ & +++ \\
$15 / 890$ & Ypresian to Lutetian & +++ & - & - & + & ++ & ++ & + \\
$15 / 896$ & Campanian to Maastrichtian & + & - & - & - & +++ & + & - \\
$15 / 898$ & Turonian to Coniacian & + & - & - & - & ++ & - & - \\
$15 / 899$ & Turonian to Coniacian & ++ & + & - & ++ & +++ & - & + \\
$15 / 904$ & Turonian to Coniacian & ++ & ++- & & +++ & ++ & + & - \\
\hline
\end{tabular}

0.83 , respectively (Tab. 7). $\mathrm{Pr} / n-\mathrm{C}_{17}$ ratios scatter within a narrow range from 0.24 to 0.54 , while $\mathrm{Ph} / n$ - $\mathrm{C}_{18}$ ratios shows slightly more variability with values between 0.31 and 0.90 . TAR values range between 0.06 and 0.69 , while only the Messinian sample (15/892) shows a significantly higher value of 1.41. OEP ratios vary between 0.74 and 1.20 and CPI ratios between 0.88 and 1.59 , with the majority being above one (Tab. 7).

Biomarker ratios could be evaluated for 9 of the 12 measured samples. Results are shown in Table. 8. Figure 5 provides representative chromatograms (Figs. 5A and 5B) as well as ion traces (Figs. 5C and 5D) for hopane $(m / z=191)$ and sterane $(m / z=217)$ identification (see also Tab. 2). The concentration of $\mathrm{C}_{28} \quad \beta \alpha \alpha$-steranes is relatively constant for all samples with $35 \% \pm 11 \%$ on average. $\mathrm{C}_{27}$ and $\mathrm{C}_{29} \beta \alpha \alpha$-steranes concentrations show a slightly larger variation $(37 \% \pm 17 \%$ and $29 \% \pm 18 \%$, respectively) and seem to be inversely proportional to each other. The Eocene samples (Ypresian to Lutetian and Bartonian to Priabonian) show slightly higher $\mathrm{C}_{29}$ concentrations compared to Turonian to Coniacian and Messinian samples (Fig. 6).

The $\mathrm{C}_{30}$ norhopane/hopane ratios are all greater than 1 with the highest value reaching 0.8 in the Messinian.
$\mathrm{C}_{26} / \mathrm{C}_{25}$ tricyclic terpanes were only evaluated in the Ypresian to Lutetian, the Bartonian to Priabonian and the Messinian samples, varying between 0.68 and 0.95 , except for the Messinian with a ratio of 0.13 (Tab. 8). $\mathrm{C}_{31} \mathrm{R} / \mathrm{C}_{30}$ hopane ratio is generally smaller than 1 with exception of one Bartonian to Priabonian sample (15/872) with a value of 1.42 (Tab. 8). The ratio of steranes over hopanes varies between 0.76 and 1.63 in the Turonian to Coniacian and the Ypresian to Lutetian samples and between 0.19 and 0.61 for the Bartonian to Priabonian and the Messinian samples (Tab. 8).

Thermal maturity parameters such as $\mathrm{C}_{29} \alpha \alpha \alpha \mathrm{S} 20 /$ $(20 \mathrm{~S}+20 \mathrm{R})-$, or $\mathrm{C}_{29} \alpha \beta \beta /(\alpha \alpha \alpha+\alpha \beta \beta)$ steranes, and $T_{\mathrm{s}} /$ $\left(T_{\mathrm{s}}+T_{\mathrm{m}}\right)$ are all $\leq 0.5$ indicating $\mathrm{OM}$ of low thermal maturity.

\section{Discussion}

\subsection{Depositional environment}

The 122 analyzed samples of Late Cretaceous to Messinian age are mainly dominated by argillaceous carbonates to almost pure limestones (12-99 wt.\% carbonate), revealing 

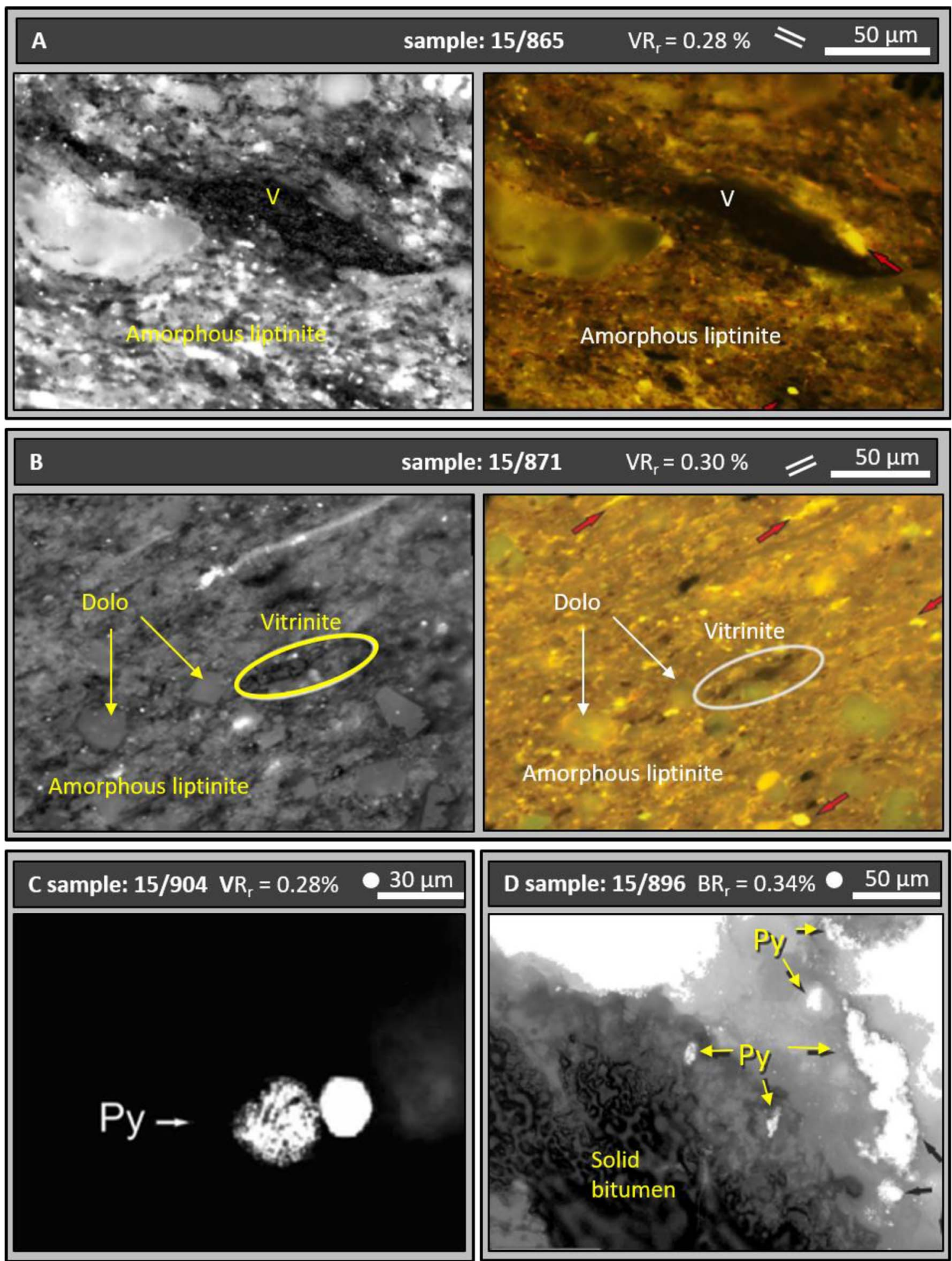

Fig. 4. Photomicrographs: || indicate bedding orientation. no bedding observable. A: Incident light (left) and ultraviolet light (right). Vitrinite particle with a highly structured surface surrounded by a fine grained matrix and amorphous liptinite. Red arrow marks a lam alginate. B: Incident light (left) and ultraviolet light (right). Vitrinite particle with structured surface (circle) surrounded by fine grained matrix, dolomite rhombs (Dolo), amorphous liptinite and different alginites (red arrows). C: Incident light. The typical occurrence of small framboidal and euhedral pyrite (Py). A large solid bitumen accumulation within a calcareous, organic-poor matrix. Large framboidal pyrite $(\mathrm{Py})$ is observed around its border. 
Table 6. Results of vitrinite reflectance measurements $\left(\mathrm{VR}_{\mathrm{r}}\right)$, the respective measured points $(n)$ and their standard deviation (SD), as well as the calculated maximum burial temperature $\left(T_{\text {peak }}\right)$.

\begin{tabular}{llcccc}
\hline Sample & \multicolumn{1}{c}{ Age } & \%VRr & $n$ & $S D$ & $T$ peak $\left[{ }^{\circ} \mathrm{C}\right]$ \\
\hline $15 / 865$ & Bartonian to Priabonian & 0.28 & 52 & 0.06 & 33 \\
$15 / 871$ & Bartonian to Priabonian & 0.25 & 48 & 0.03 & 24 \\
$15 / 886$ & Ypresian to Lutetian & 0.30 & 11 & 0.03 & 39 \\
$15 / 890$ & Ypresian to Lutetian & 0.24 & 3 & 0.01 & 20 \\
$15 / 899$ & Turonian to Coniacian & 0.29 & 22 & 0.05 & 36 \\
$15 / 904$ & Turonian to Coniacian & 0.28 & 31 & 0.07 & 33 \\
\hline
\end{tabular}
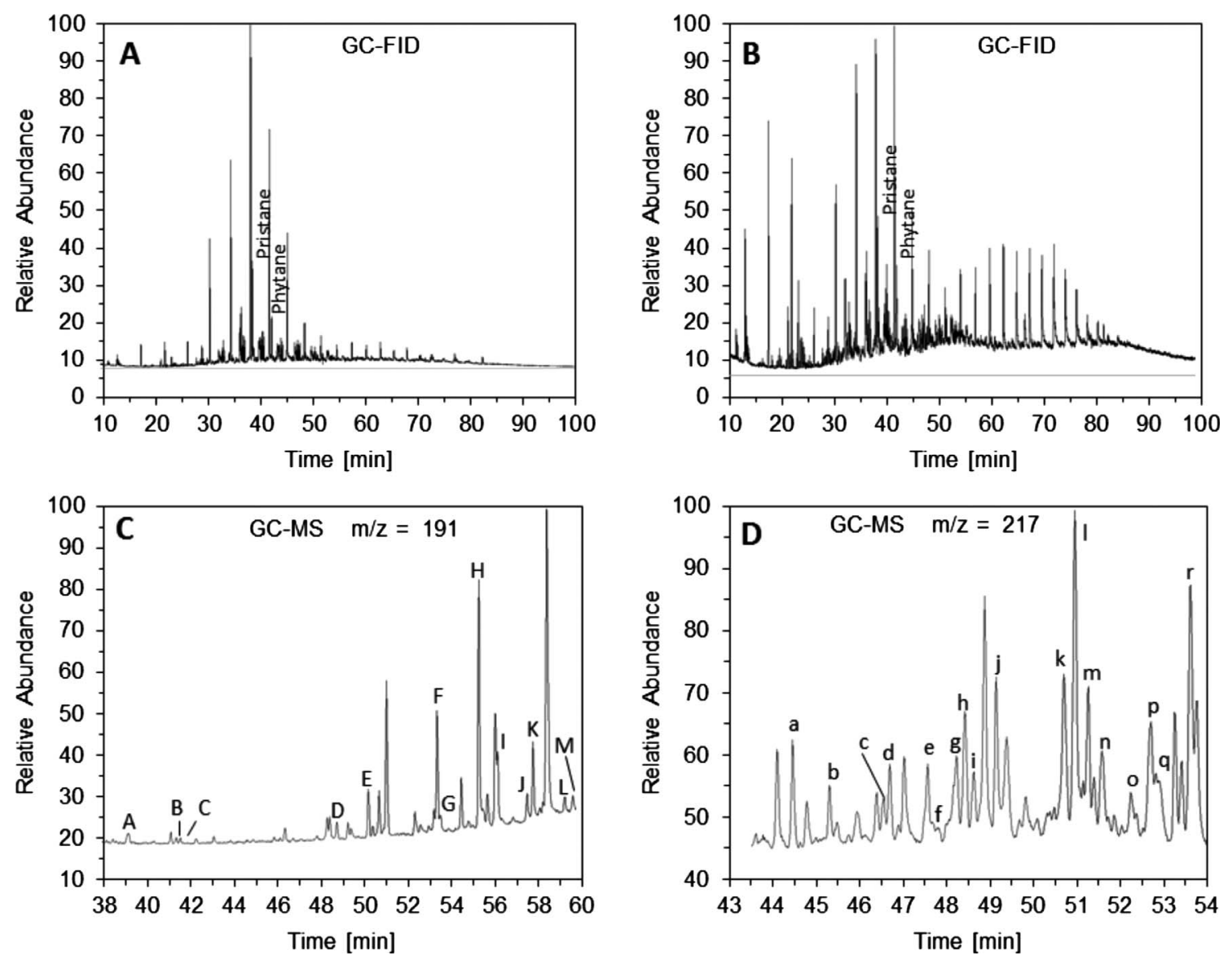

Fig. 5. Representative gas chromatographs for the aliphatic hydrocarbon fraction (A) Sample $15 / 906$ shows a clear predominance of medium-chain $n$-alkanes $\left(n-\mathrm{C}_{12}-n\right.$ - $\left.\mathrm{C}_{20}\right)$ with almost no longer chain molecules. (B) Sample $15 / 899$ illustrates a predominance of medium-chain $n$-alkanes over abundant long-chain $n$-alkanes $\left(n-\mathrm{C}_{21}-n\right.$ - $\left.\mathrm{C}_{35}\right)$. (C) Partial m/z 191 mass fragmentograms showing hopane distributions for sample 15/890. (D) Partial m/z 217 mass fragmentograms showing sterane distributions for sample $15 / 872$. Peak identifications are provided on Table 2.

a high variability in their organic content $(0-9.3$ wt.\%) (Fig. 3). Samples enriched in OM are mainly attributed to the Eocene (especially to the Upper Eocene, Bartonian to Priabonian) and to the Lower Upper Cretaceous (Turonian to Coniacian) intervals. Petrographic investigations show that the OM in these rocks is mainly composed of alginites and submicroscopic organic matter, which are typically derived from marine organisms. These observations are supported by several molecular-geochemical ratios such as TAR and $\operatorname{Pr} / \mathrm{Ph}<<2$, which are common in marine environments (Peters et al., 2005). Also the relative concentrations of $\mathrm{C}_{27}$ to $\mathrm{C}_{28}$ and $\mathrm{C}_{29} \beta \alpha \alpha$-steranes (Fig. 6) match those observed in open marine environments (Peters et al., 2005). 
Table 7. Molecular geochemical ratios from GC-FID analysis. $\mathrm{Pr}=$ pristane; $\mathrm{Ph}=$ phytane; $\mathrm{TAR}=$ terrigeneous $/$ aquatic ratio; $\mathrm{OEP}=$ Odd Even Predominance; $\mathrm{CPI}=$ Carbon preference Index.

\begin{tabular}{llcccccc}
\hline Sample & \multicolumn{1}{c}{ Age } & $\mathrm{Pr} / \mathrm{Ph}$ & $\mathrm{Pr} / n$ - $\mathrm{C}_{17}$ & $\mathrm{Ph} / n$ - $\mathrm{C}_{18}$ & $\mathrm{TAR}$ & OEP & CPI \\
\hline $15 / 892$ & Messinian & 0.50 & 0.53 & 0.89 & 1.41 & 0.74 & 0.88 \\
$15 / 895$ & Eocene to Miocene & 1.30 & 0.50 & 0.51 & 0.10 & 0.76 & 1.38 \\
$15 / 864$ & Bartonian to Priabonian & 1.49 & 0.24 & 0.31 & 0.07 & 0.83 & 1.23 \\
$18 / 867$ & Bartonian to Priabonian & 1.58 & 0.37 & 0.49 & 0.13 & 1.07 & 1.41 \\
$15 / 868$ & Bartonian to Priabonian & 0.49 & 0.33 & 0.90 & 0.69 & 1.16 & 1.59 \\
$15 / 872$ & Bartonian to Priabonian & 1.25 & 0.25 & 0.39 & 0.22 & 1.04 & 1.58 \\
$15 / 888$ & Ypresian to Lutetian & 0.83 & 0.52 & 0.73 & 0.39 & 0.88 & 1.29 \\
$15 / 890$ & Ypresian to Lutetian & 1.41 & 0.36 & 0.39 & 0.11 & 0.85 & 1.03 \\
$15 / 899$ & Turonian to Coniacian & 1.48 & 0.54 & 0.49 & 0.56 & 1.11 & 1.13 \\
$15 / 902$ & Turonian to Coniacian & 1.17 & 0.38 & 0.50 & 0.32 & 1.20 & 1.58 \\
$15 / 903$ & Turonian to Coniacian & 1.00 & 0.31 & 0.41 & 0.20 & 0.99 & 1.29 \\
$15 / 906$ & Turonian to Coniacian & 1.49 & 0.32 & 0.31 & 0.06 & 0.94 & 0.94 \\
\hline
\end{tabular}

Table 8. Various biomarker ratios from GC-MS analysis. [-]: not determined.

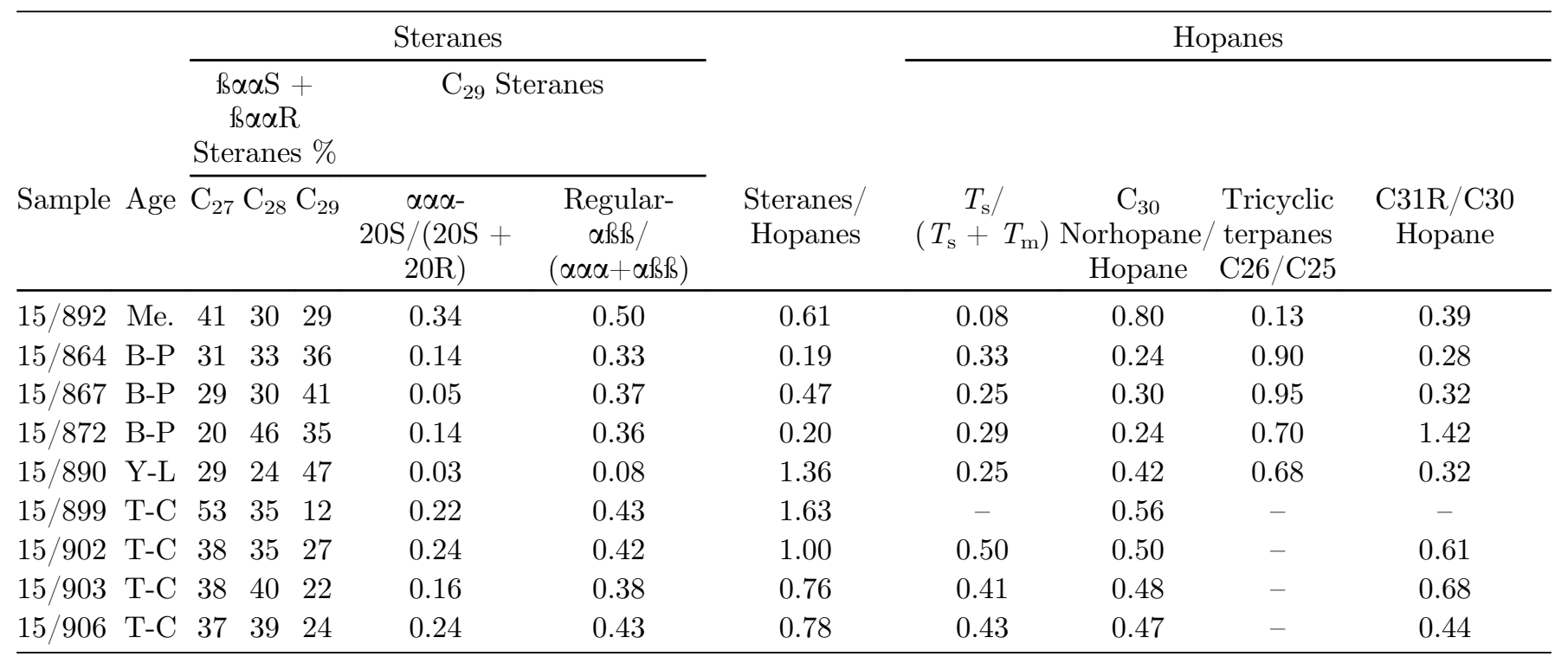

In view of the predominance of marine OM, many of the analyzed samples show exceptional high OI values measured on bulk rock samples by Rock-Eval pyrolysis, causing a broad scatter between marine Type II and terrestrial Type III kerogen in the modified van Krevelen diagram (after Tissot and Welte, 1984) (Fig. 7A). A more clear correlation with Type II kerogen can be observed in the TOC vs. S2 plot (Fig. 7B). This ambiguity can be either caused by oxidized $\mathrm{OM}$ or by additional $\mathrm{CO}_{2}$ generation from the decomposition of carbonates (Katz, 1983). The first possibility is assumed to be less likely in this case, since petrographic analysis reveals, mainly fresh, unaltered pyrite crystals, which are usually more vulnerable to weathering than OM (Littke, 1993). Alternatively, additional $\mathrm{CO}_{2}$ generation seems to be a more reasonable explanation, as this effect is known for immature carbonates (Katz, 1983), which are supposed to be present in the analyzed samples. Furthermore, this interpretation is supported by the Rock-Eval results repeated on the HCl-treated samples. As illustrated in Figure 8, these $\mathrm{HCl}$-treated samples have lower OI and higher HI values, show less scattering and plot closer to the Type II kerogen pathway compared to the respective untreated samples. Therefore, results might be inaccurate for low mature, carbonate-rich samples analyzed by bulk rock Rock-Eval pyrolysis only. Although this is the standard technique applied in petroleum exploration, we 


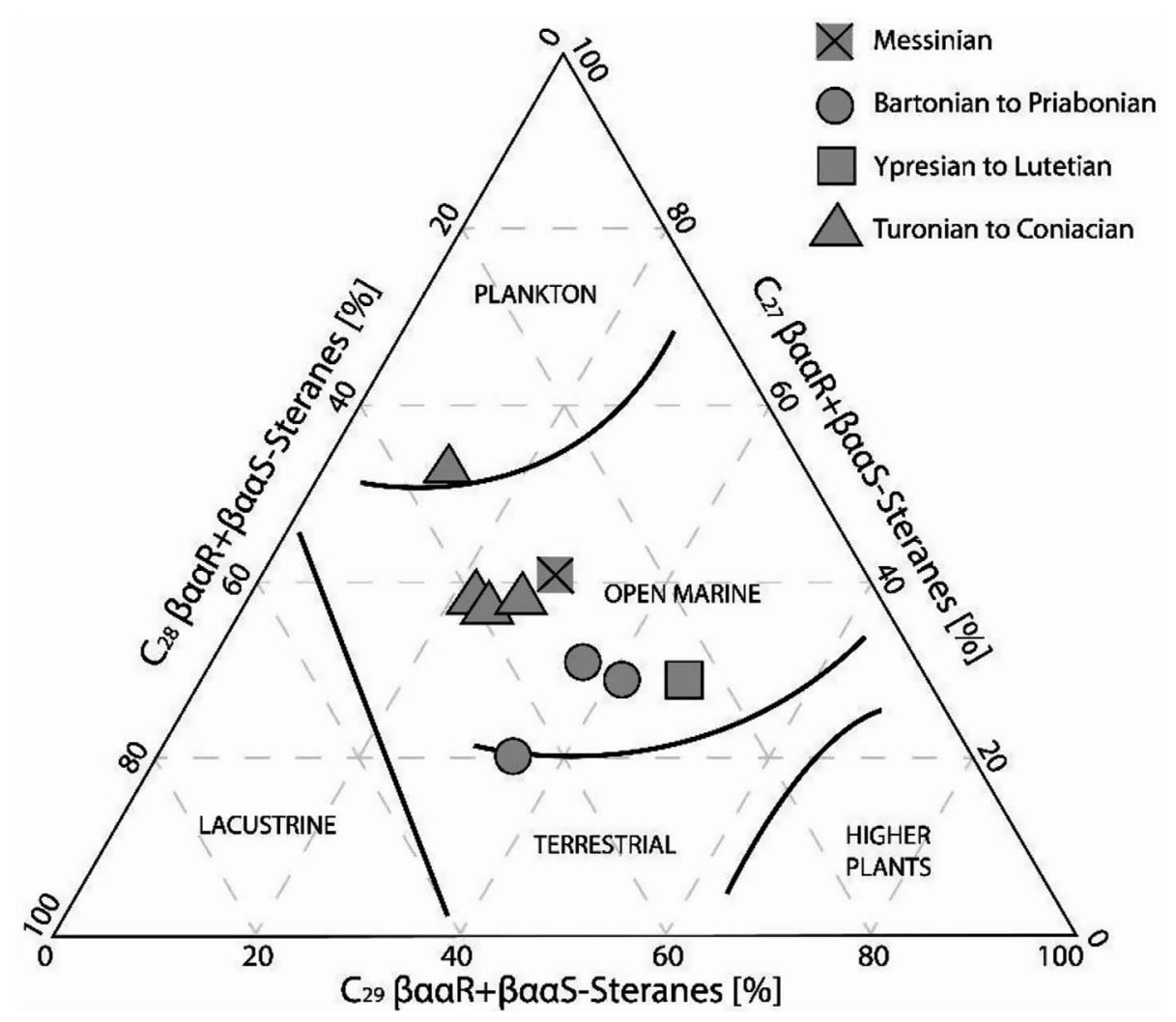

Fig. 6. $\mathrm{C}_{27}$ to $\mathrm{C}_{29} \beta \alpha \alpha$ sterane distribution indicating an open marine environment as source for the OM. Eocene samples (Bartonian to Priabonian and Ypresian to Lutetian) show a slightly higher concentration of $\mathrm{C}_{29} \beta \alpha \alpha$ sterane concentrations. Paleoenvironmental and source interpretation after Hatem et al. (2016) (modified after Huang and Meinschein, 1979).

recommend here to perform Rock-Eval pyrolysis directly on $\mathrm{HCl}$-treated samples to avoid possible bias in the results.

The clear predominance of marine over terrestrial $\mathrm{OM}$ is expected based on the rather isolated position of the ESM at present and also during its past, not favoring any large-scale deposition of terrestrial OM. The very rare terrestrial $\mathrm{OM}$ which could be observed might originate from the northern African margin, which was the closest landmass in the greater surrounding of the ESM during its past (Robertson et al., 2012). High amounts of clastic, terrestrial material were shed into the Eastern Mediterranean basins by the Nile Delta (Sestini, 1989; Hawie et al., 2013, Nader, 2014).

The positive correlation between TS and TOC (Fig. 7C) suggests a dependency of sulfate reduction on the availability of OM, which is usually the case in marine depositional environments. However, all samples plot below the "normal marine line" (Berner, 1984). This observation usually hints to fresh water environments. Sulfur is mainly incorporated into the sediment in the form of pyrite, which requires a distinct amount of reactive iron (Berner, 1984). In highly calcareous systems, such as the ESM, the availability of iron is usually low (Berner, 1984). This assumption is supported by low Fe concentrations which are observed along the ESM $(<<1000$ ppm, Emeis et al., 1996). This lack of reactive iron inhibits the formation of pyrite and, therefore, explains the unusual low TS values. $\mathrm{Pr} / n-\mathrm{C}_{17}$ vs. $\mathrm{Ph} / n-\mathrm{C}_{18}$ ratios (Fig. 9) suggest a deposition and preservation of OM under dysoxic conditions. The presence of oxygen depleted, yet not completely anoxic bottom waters is further supported by $\mathrm{C}_{30}$ norhopane/hopane ratios $<1$ (Peters et al., 2005).

Until the Middle Eocene, the ESM was located within an open oceanic basin (Robertson et al., 2012). Therefore, water stagnation as a control of oxygen depletion, as it is often attributed to restricted basins (Littke, 1993), seems to be highly unlikely for the pre-Eocene strata. Thus, redox conditions might have been controlled by events of increased bio-productivity in the photic zone above the ESM with subsequent export of OM to the seafloor which lead to oxygen depletion through microbial respiration and $\mathrm{OM}$ degradation. High bioproductivity leads in such cases to enhanced oxygen depletion and both higher quantities and better preservation of OM (e.g. Littke, 1993). Effects causing such an increased bioproductivity in marine environments may be attributed to upwelling systems, where uprising cold, nutrient-rich waters enhance primary productivity rates (Littke, 1993). High bioproductivity along the eastern Mediterranean shelf has already been documented for the Campanian-Maastrichtian and was attributed to an extensive upwelling system which cause extensive deposition of high quality source rocks (e.g. Bou Daher et al., 2015). However, extent and frequency of organic-rich intervals on the ESM are rather low and 

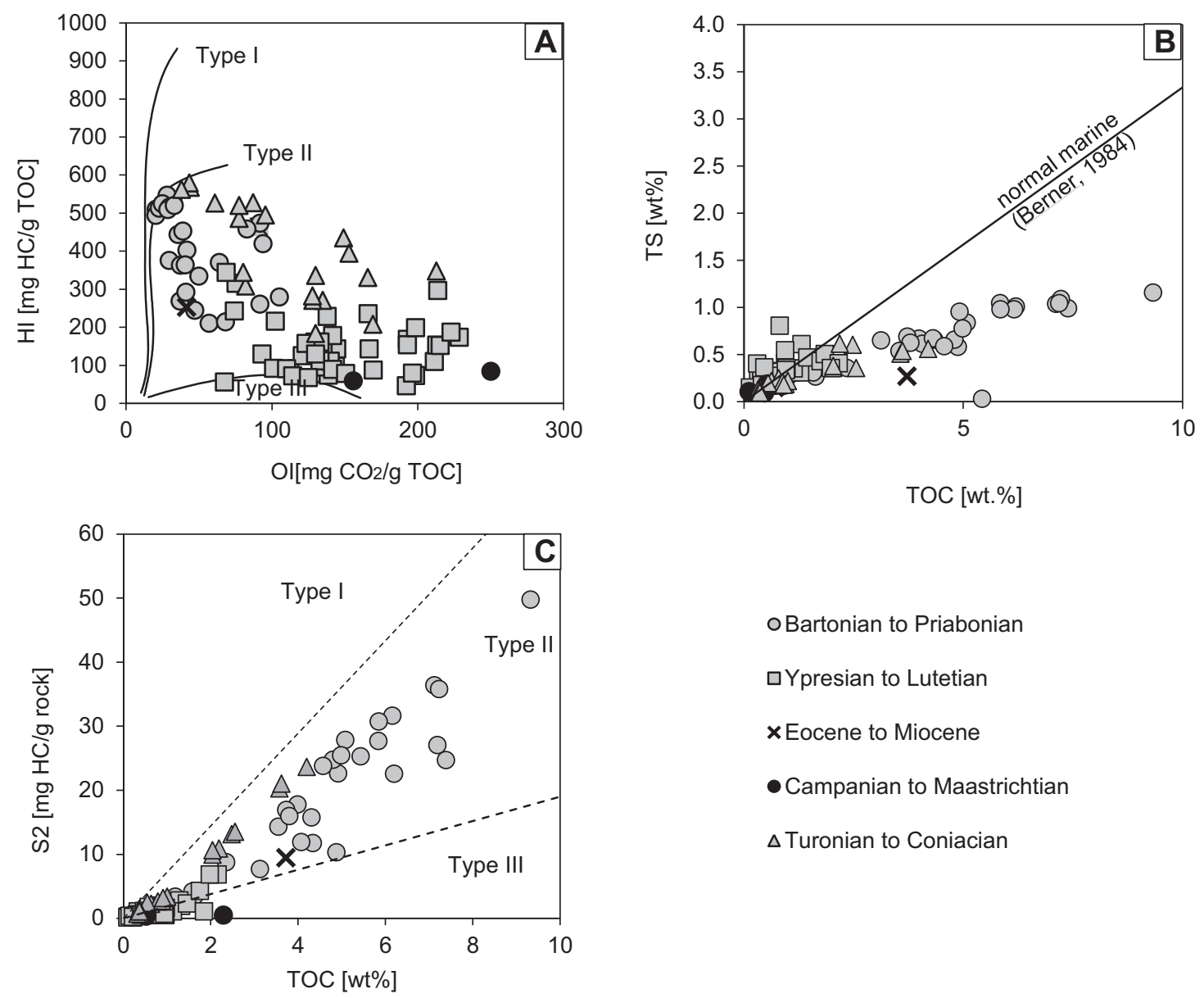

\author{
oBartonian to Priabonian \\ 口Ypresian to Lutetian \\ x Eocene to Miocene \\ - Campanian to Maastrichtian
}

$\Delta$ Turonian to Coniacian

Fig. 7. (A) The samples in the pseudo van Krevelen diagram scatter from Type II to Type III. (B) In the TOC vs. S2 diagram, most samples plot within the Type II area. (C) All samples in the TOC-TS diagram show a positive correlation but plot below the normal marine line derived from Berner (1984) indicating a lack of iron to precipitate pyrite.

the majority of the sediments show low or no organic matter content. Upwelling systems around seamounts are very sensitive and depend on a complex interplay of e.g. climatic conditions, wind and ocean currents, as well as sea level fluctuations. Thus, their occurrence can be limited to short periods, sometimes only few weeks or even days (Genin and Boehlert, 1985). Such a sensitive, rarely occurring event might have been responsible for the deposition of the present organic-rich intervals. Further, the zone of oxygen-depletion evolving along upwelling regions is quite narrow and located in the upper water column (Suess and Thiede, 1983). Therefore, the extent of the organic-rich intervals is expected to be limited to the surrounding of the ESM as it was shown for the Eastern Levant margin, where organic richness in Cretaceous sediments decreases towards the Levant Basin (Bou Daher et al. 2015).

According to the geochemical results, the Eocene intervals were also deposited under dysoxic conditions, supporting the idea of occasional upwelling-related enhanced bioproductivity being responsible for the deposition of the OM-rich intervals. However, the lateral distribution might extend further towards the surrounding basins. With the ongoing convergence and subduction of Afro-Arabia below the Eurasian plate, the Mediterranean basin became more and more restricted since the Mid-Eocene by narrowing its connection to the Indian Ocean in the east with the final closure and isolation in the Early-Middle Miocene (Robertson et al., 2012). This isolation might have favored the evolution of water stagnation and anoxic bottom waters in the deeper parts of the basin. Thus, primary deposition and/or redeposition of the Upper Eocene intervals (e.g. mass transport deposits such as turbidities) might have led to the deposition and preservation of organic-rich intervals also towards the deeper parts of the basins.

\subsection{Source rock potential and thermal maturity}

Based on the TOC vs. S2 classification by Peters et al. (2005) and a critical threshold value of $0.3 \mathrm{wt} . \%$ TOC for calcareous source rocks (Hunt, 1967) the petroleum generation potential for 46 of the 122 analyzed samples is of at least fair quality (Fig. 10). These samples belong mainly to the Turonian to Coniacian intervals containing OM of fair to very good quality (averages: $\mathrm{TOC}=0.93$ wt.\%, $\mathrm{S} 2=$ $2.92 \mathrm{mg} \mathrm{HC} / \mathrm{g}$ rock, $\mathrm{HI}=319 \mathrm{mg} \mathrm{HC} / \mathrm{g}$ TOC), and the Bartonian to Priabonian samples, which even reach very 


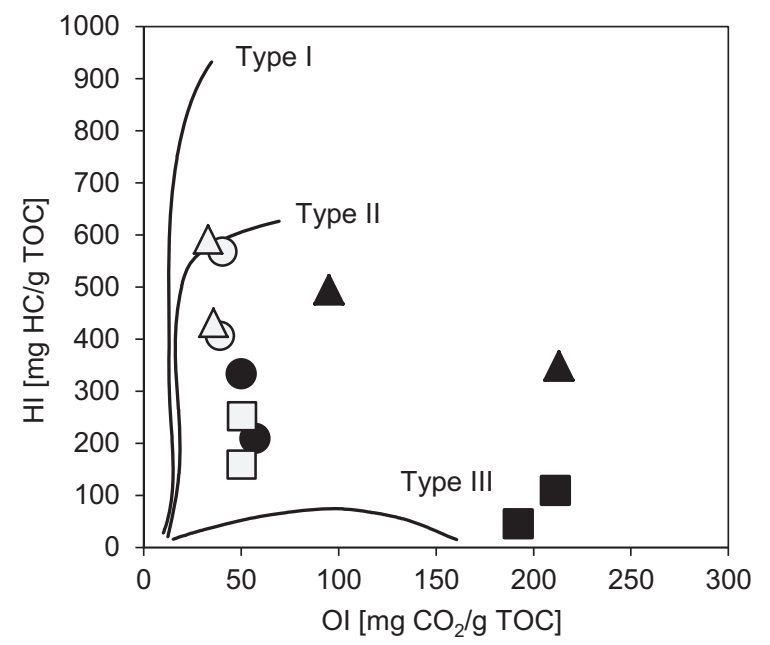

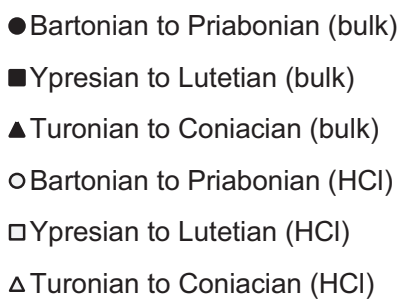

Fig. 8. Comparison of bulk and HCl-treated samples in the pseudo van Krevelen diagram. OI values are decreased while HI values are increased. The effect is more prominent for low TOC samples (see Table 4).

good to excellent $\mathrm{OM}$ quality (averages: $\mathrm{TOC}=4.8 \mathrm{wt} . \%$, $\mathrm{S} 2=22.52 \mathrm{mg} \mathrm{HC} / \mathrm{g}$ rock, $\mathrm{HI}=469 \mathrm{mg} \mathrm{HC} / \mathrm{g}$ TOC). The OM in these rocks is mainly composed of oil-prone Type II kerogen. As mentioned before, Rock-Eval results obtained from untreated immature carbonate samples have to be interpreted with caution as they might lead to an overestimation of the OI values and underestimation of the HI values. Therefore, the quality of OM and the actual source rock potential might be misinterpreted if only based on low mature, carbonate-rich whole bulk rock samples.

All analyzed intervals are thermally immature as it is implied by low S1 peaks, PI values below 0.1, low $T_{\max }$ values of $412{ }^{\circ} \mathrm{C}-434{ }^{\circ} \mathrm{C}$, low $\mathrm{VRr}$ of $0.26 \%-0.28 \%$ and the golden-yellow fluorescence of alginite macerals (Hunt, 1995; Peters, 1986, Peters et al., 2005). These results are further supported by several biomarker ratios such as $T_{\mathrm{s}} /\left(T_{\mathrm{s}}+T_{\mathrm{m}}\right)<0.5$ or the ratio $20 \mathrm{~S} /(20 \mathrm{~S}+20 \mathrm{R}) \alpha \alpha \alpha-$ steranes $<0.34$. Maturity differences are too small, so no clear trend of maturity indicators with relative age could be observed. High HI values, especially in the Lower Upper Eocene (Turonian to Coniacian) and Upper Eocene (Bartonian to Priabonian) intervals indicate high potential of yet to be cracked hydrocarbon (HC). However, thermal maturity and $\mathrm{HC}$ contribution to working petroleum systems might be enabled for Upper Eocene intervals in deeper parts of the basins (see Sect. 5.1), where deeper burial depths of up to $5 \mathrm{~km}$ are reached (Montadert et al., 2014).

\subsection{Implications for potential petroleum systems}

Today, the major gas fields in the Levant Basin, either located in Miocene clastic turbidite reservoirs (e.g. Tamar, Leviathan, Aphrodite) or in Mesozoic shallow water carbonates (Zohr) mainly comprise natural gas of biogenic origin (e.g. Feinstein et al., 2002, Schenk et al., 2010; Bertello et al., 2016). Nevertheless, many reservoirs containing also thermogenic $\mathrm{HC}$ accumulations have been proven along the Nile Delta, which are probably charged by mature source rocks of Mid Jurassic to pre-Messinian age (e.g. Aal et al., 2000; Vandré et al., 2007). Triassic source rocks are known to have sourced oil and gas reservoirs in Syria and Iraq (May, 1991; Lie et al., 2011). Along the eastern Levant margin offshore Israel, thermogenic gas has been proven in Jurassic and Lower Cretaceous intervals (Feinstein et al., 2002). Furthermore, the presence of thermogenic petroleum systems at the eastern margin of the Levant Basin is also indicated by asphalt shows in Upper Cretaceous intervals onshore Lebanon (Nader, 2014). Bou Daher et al. (2016) and Nader et al. (2018) have shown that source rocks of Jurassic-Cretaceous and Cretaceous-OligoMiocene age might have reached thermal maturity along the Levant margin and the deeper parts of the Levant Basin.

For the present study area (offshore Cyprus), potential source rock intervals were proven in the Lower Upper Cretaceous and the Upper Eocene. These immature intervals identified here could be considered as a potential source of biogenic gas, which is produced at shallow burial depths (e.g. Rice and Claypool, 1981; Stolper et al., 2014). Furthermore, the presence of thermally mature source rocks in the sedimentary cover of the ESM or its surrounding is indicated by solid bitumen staining, which could be observed in one Lower Eocene (Ypresian to Lutetian) and one Upper Cretaceous (Campanian) sample. $\mathrm{VR}_{\mathrm{r}}$ reflectance of overlying and underlying sampled intervals is low $(0.25 \%-0.3 \%$; Tab. 6) and refers to an experienced $T_{\text {peak }}$ temperature of only $20{ }^{\circ} \mathrm{C}-36{ }^{\circ} \mathrm{C}$, which is in accordance with presentday burial and temperature conditions. Therefore, these solid bitumens must be derived from deeper buried source rocks, since the thermal maturity in the sampled intervals is too low to allow oil generation. Such mature source rocks might occur, as mentioned above, in deeper parts of the basins or probably in older Mesozoic units, which were not drilled and, therefore, could not be investigated. Nevertheless, as outlined above, onshore investigations have identified several events of source rock deposition in the sedimentary succession along the eastern and southern Levant margin, which might extend towards the deeper Levant Basin. Although the basin ward extent of potential source rocks is unknown, the study conducted by Roberts and Peace (2007) on oil seepage in the Eastern Mediterranean Sea indicates $\mathrm{HC}$ generation and potential prospects along the northwestern, northern and southwestern flanks of the ESM. On several seismics e.g., flat spots can be observed which indicate gas accumulations in Upper Cretaceous anticlinal structures (Roberts and Peace, 2007) and, therefore, imply the presence of thermally mature Mesozoic source rocks within the basin. 


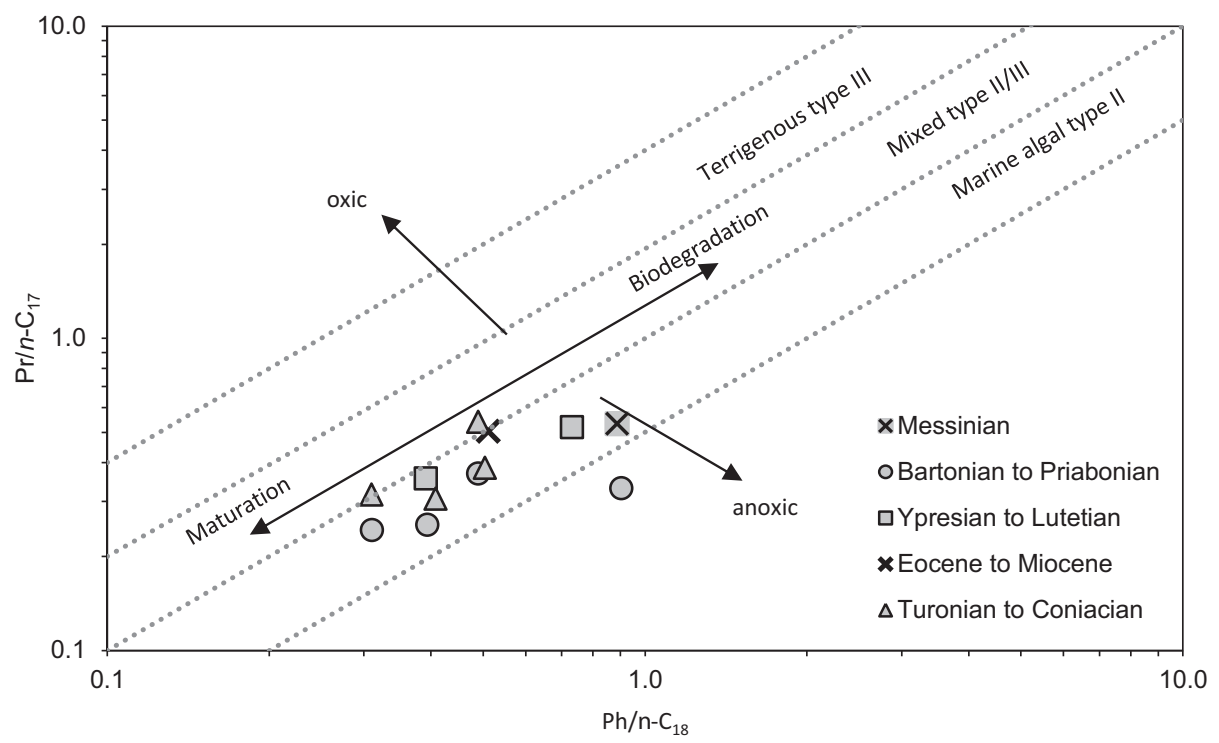

Fig. 9. Typical plot of $\mathrm{Pr} / n-\mathrm{C}_{17}$ vs. $\mathrm{Ph} / n$ - $\mathrm{C}_{18}$ ratios for offshore Cyprus samples indicating marine organic matter deposited under mainly dysoxic conditions (modified from Hunt, 1995).

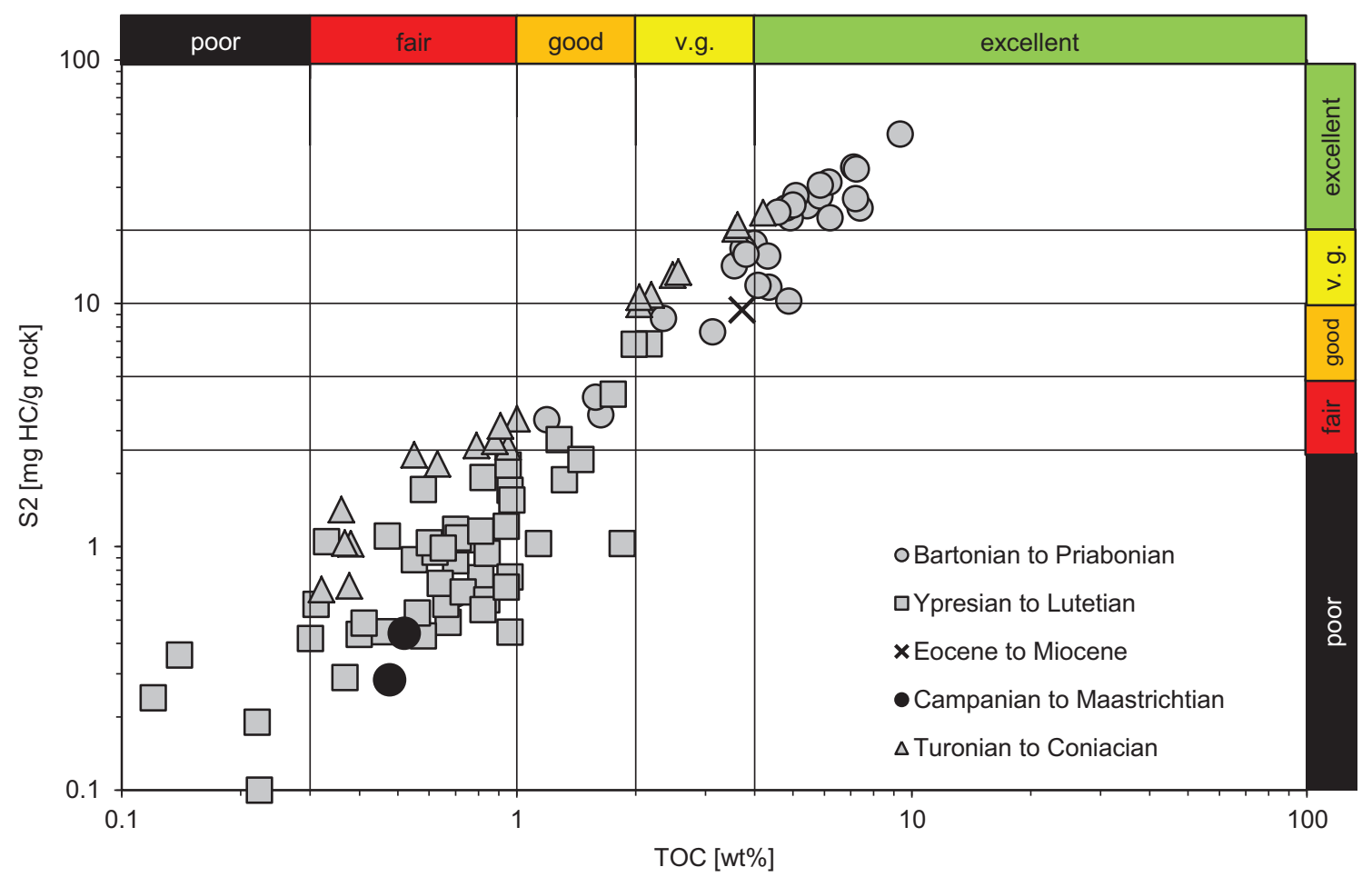

Fig. 10. Source rock potential and thermal maturity evaluation based on the TOC vs. S2 classification.

At the same time, the presence of cavities filling solid bitumen in the immature, otherwise organic-poor samples further demonstrate the existence of a pore interconnectivity allowing hydrocarbon migration from deeper, thermally mature regions up to these shallow intervals. Most investigated samples contain few pyrite grains, but in the vicinity of the solid bitumen accumulations large framboidal pyrite clusters occur (Fig. 4). This is an indicator of fluid migration through these rocks at temperatures lower than approximately $80^{\circ} \mathrm{C}$, suitable for sulphate reducing, bacterial activity (e.g. Cord-Ruwisch et al., 1987; Schauder and Kröger, 1993). Fluid mobility may also have been enhanced during extensive dissolution of minerals by meteoric water flushing during the 
subaerial exhumation of the ESM at times of the Messinian Salinity Crisis (MSC) providing potential HC migration pathways.

Potential reservoir structures might be found in turbidites derived from the basin margins and the Nile Cone Delta or within the karstified Mesozoic to Cenozoic carbonates of the ESM (such as Zohr and Calypso). These reservoirs would be sealed by thick Messinian evaporites and trapped by abrupt facies changes along the ESM margins that are inferred from seismic data (Montadert et al., 2014, Papadimitriou et al., 2018).

\section{Conclusion}

The geochemical and petrological data of 122 investigated samples of Late Cretaceous to Messinian age presented in this study adds valuable information on source rock intervals to the underexplored deep water frontier area of the Eratosthenes Seamount (ESM), offshore Cyprus:

- The analyzed samples comprise mainly argillaceous carbonates to pure limestones (12-99 wt.\% carbonate) with highly varying amounts of marine Type II kerogen (0-9.3 wt.\% TOC).

- TS/TOC and several biomarker ratios indicate deposition and preservation of OM under dysoxic conditions, which were probably reached during rare and short upwelling events.

- Promising source rock intervals were mainly deposited in the Lower Upper Cretaceous (Turonian to Coniacian; averages: $\mathrm{TOC}=0.93$ wt.\%, $\mathrm{HI}=319$ $\mathrm{mg} \mathrm{HC} / \mathrm{g}$ TOC) and in the Upper Eocene (Bartonian to Priabonian; averages: $\mathrm{TOC}=4.8$ wt. $\%, \mathrm{HI}=$ $469 \mathrm{mg} \mathrm{HC} / \mathrm{g}$ TOC), and are of fair to good and good to excellent quality, respectively. However, determination of their vertical extent is inhibited by a low core recovery rate.

- Rock-Eval analysis of HCl-treated samples showed here that the kerogen quality might be underestimated if based on bulk rock observations only.

- The Upper Eocene source rocks might continue towards the basins center, if anoxic bottom waters evolved during the isolation of the Eastern Mediterranean since the Mid-Eocene.

- All analyzed samples are immature. However, the presence of thermal mature source rocks in the sedimentary cover of the ESM or its surrounding is indicted by solid bitumen staining, which could be observed in Lower Eocene intervals.

- Karstified Late Cretaceous to Cenozoic carbonates on the ESM or turbidities along its slope might provide potential reservoir structures, which would be sealed by Messinian salt.

Acknowledgments. The authors express their gratitude to the International Ocean Discovery Program and its core repository team in Bremen for granting the access to the ODP Leg 160 cores. The authors would like to thank as well Ms. Lesche for assistance during laboratory analyses at RWTH Aachen. Two anonymous reviewers are also thanked for providing detailed and constructive comments on an earlier draft of this manuscript.

\section{References}

Aal A.A., El Barkooky A., Gerrits M., Meyer H., Schwander M., Zaki H. (2000) Tectonic evolution of the Eastern Mediterranean Basin and its significance for hydrocarbon prospectivity in the ultra-deepwater of the Nile Delta, The Leading Edge 19, 10, 1086-1102.

Barker C.E., Pawlewicz M.J. (1993) An empirical determination of the minimum number of measurements needed to estimate the mean random vitrinite reflectance of disseminated organic matter, Org. Geochem. 20, 6, 643-651.

Barker C.E., Pawlewicz M.J. (1994) Calculation of Vitrinite Reflectance from Thermal Histories and Peak Temperatures A Comparison of Methods, in: Mukhopadhyay P.K., Dow W.G. (eds), Reevaluation of Vitinite Reflectance, ACS Symposium Series 570, 216-229.

Behar F., Beaumont V., de B. Penteado H.L. (2001) Rock-Eval 6 technology: performances and developments, Oil Gas Sci. Technol. - Rev. IFP Energies nouvelles 56, 2, 111-134.

Berner R.A. (1984) Sedimentary pyrite formation: an update, Geochim. Cosmochim. Acta 48, 4, 605-615.

Bertello F., Harby H., Brandolese S. (2016) Egypt: Zohr, an outstanding gas discovery in a new deep-water hydrocarbon play, In: 8th Mediterranean Offshore Conference and Exhibition, Alexandria, Egypt.

Beydoun Z.R. (1991) Arabian plate hydrocarbon geology and potential - a plate tectonic approach, AAPG Stud. Geol. 33, 77.

Bou Daher S., Ducros M., Michel P., Hawie N., Nader F.H., Littke R. (2016) 3D thermal history and maturity modelling of the Levant Basin and its eastern margin, offshore-onshore Lebanon, Arab. J. Geosci. 9, 6, 440.

Bou Daher S., Nader F.H., Müller C., Littke R. (2015) Geochemical and petrographic characterization of Campanian-Lower Maastrichtian calcareous petroleum source rocks of Hasbayya, South Lebanon, Mar. Petrol. Geol. 64, 304-323.

Bou Daher S., Nader F.H., Strauss H., Littke R. (2014) Depositional environment and source-rock characterization of organic-matter rich Upper Santonian-Upper Campanian carbonates, northern Lebanon, J. Petrol. Geol. 37, 1, 5-24.

Bourbonniere R.A., Meyers P.A. (1996) Sedimentary geolipid records of historical changes in the watershed and productivities of Lake Ontario and Erie, Limnol. Oceanogr. 41, 352-359.

Bray E.E., Evans E.D. (1961) Distribution of n-paraffins as a clue to recognition of source beds, Geochim. Cosmochim. Acta 22, 2-15.

Choquette P.W., Pray L.C. (1970) Geologic nomenclature and classification of porosity in sedimentary carbonates, $A A P G$ Bull. 54, 2, 207-250.

Cord-Ruwisch R., Kleinitz W., Widdle F. (1987) Sulfatereducing bacteria and their activities in oil production, $J$. Petrol. Tech. 39, 1, 97-106.

Emeis K.C., Robertson A.H.F., Richter C. et al. (1996) Proc. ODP, Init. Repts, 160: College Station, TX (Ocean Drilling Program).

Eni (2018) Eni announces a gas discovery Offshore Cyprus, Retrieved from http://www.eni.com/docs/en_IT/enicom/ media/press-release/2018/02/PR_Eni-Cyprus_Calypso.pdf 
Esestime P., Hewitt A., Hodgson N. (2016) Zohr - a newborn carbonate play in the Levantine Basin, East-Mediterranean, First Break 34, 87-93.

Espitalié J., Laporte J.L., Madec M., Marquis F., Leplat P., Paulet J., Boutefeu A. (1977) Méthode rapide de caractérisation des roches mètres, de leur potentiel pétrolier et de leur degré d'évolution, Oil Gas Sci. Technol. - Rev. IFP Energies nouvelles 32, 1, 23-42.

Feinstein S., Aizenshtat Z., Miloslavski I., Gerling P., Slager J., McQuilken J. (2002) Genetic characterization of gas shows in the east Mediterranean offshore of southwestern Israel, Org. Geochem. 33, 12, 1401-1413.

Galindo-Zaldivar J., Nieto L., Robertson A., Woodside J. (2001) Recent tectonics of Eratosthenes Seamount: an example of seamount deformation during incipient continental collision, Geo Mar. Lett. 20, 4, 233-242.

Gardosh M.A., Druckman Y. (2006) Seismic stratigraphy, structure and tectonic evolution of the Levantine Basin, offshore Israel, Geol. Soc. Spec. Publ. 260, 1, 201-227.

Genin A., Boehlert G.W. (1985) Dynamics of temperature and chlorophyll structures above a seamount: an oceanic experiment, J. Mar. Res. 43, 4, 907-924.

Ghalayini R., Daniel J.M., Homberg C., Nader F.H., Comstock J.E. (2014) Impact of Cenozoic strike-slip tectonics on the evolution of the northern Levant Basin (offshore Lebanon), Tectonics 33, 11, 2121-2142.

Hatem B.A., Abdullah W.H., Hakimi M.H., Mustapha K.A. (2016) Origin of organic matter and paleoenvironment conditions of the Late Jurassic organic-rich shales from shabwah sub-basin (western Yemen): Constraints from petrology and biological markers, Mar. Petrol. Geol. 72, 83-97.

Hawie N., Gorini C., Deschamps R., Nader F.H., Montadert L., Granjeon D., Baudin F. (2013) Tectono-stratigraphic evolution of the northern Levant Basin (offshore Lebanon), Mar. Petrol. Geol. 48, 392-410.

Huang W.-Y., Meinschein W.G. (1979) Sterols as ecological indicators, Geochim. Cosmochim. Acta 43, 739-745.

Hunt J.M. (1967) The origin of petroleum in carbonate Rocksk11, in: Chillingar, G.V., Bissel, H.J., Fairbridge, R.W. (eds), Developments in sedimentology Vol. 9 Carbonate rocks physical and chemical aspects, Elsevier, Amsterdam, pp. 225-251.

Hunt J.M. (1995) Petroleum Geochemistry and Geology, W.H. Freeman and Company, New York, pp. 1-20.

Katz B.J. (1983) Limitations of "Rock-Eval" pyrolysis for typing organic matter, Org. Geochem. 4, 3-4, 195-199.

Lie Ø., Skiple C., Lowrey C. (2011) New insights into the Levantine Basin, Geo ExPro 8, 1, 24-27.

Littke R. (1993) Deposition, diagenesis and weathering of organic matter-rich sediments, in: Bhattacharji S., Friedmann G.M., Neugebauer H.J., Seilacher A. (eds), Lecture Notes in Earth Sciences, Springer, Berlin, pp. 22-27, 169-182.

May P.R. (1991) The eastern Mediterranean Mesozoic Basin: evolution and oil habitat (1), AAPG Bull. 75, 7, 1215-1232.

Montadert L., Nicolaides S., Semb P.H., Lie Ø. (2014) Petroleum systems offshore Cyprus, in: Marlow L., Kendall C., Yose L. (eds), AAPG special volumes memoir 160: Petroleum systems of the Tethyan region, AAPG, Tulsa, OK, pp. 301-334.

Nader F.H. (2014) Insights into the petroleum prospectivity of Lebanon, in: Marlow L., Kendall C., Yose L. (eds), AAPG Special volumes memoir 160: Petroleum systems of the Tethyan region, AAPG, Tulsa, OK, pp. 241-278.
Nader F.H., Inati L., Ghalayini R., Hawie N., Bou Daher S. (2018) Key geological characteristics of the Saida-Tyr Platform along the eastern margin of the Levant Basin, offshore Lebanon: implications for hydrocarbon exploration, Oil Gas Sci. Technol. - Rev. IFP Energies nouvelles, this volume.

Naylor D., Al-Rawi M., Clayton G., Fitzpatrick M.J., Green P.F. (2013) Hydrocarbon potential in Jordan, J. Petrol. Geol. 36, 3, 205-236.

Needham D., Hosler J., Nowak S., Christensen C., Ffrench J. (2013) The Tamar Field from Discovery to Production (Abstract), in: AAPG Search and Discovery Article \#90161@2013, AAPG European Conference.

Netzeband G.L., Gohl K., Hübscher C.P., Ben-Avraham Z., Dehghani G.A., Gajewski D., Liersch P. (2006) The Levantine Basin - crustal structure and origin, Tectonophysics 418, 3-4, 167-188.

Papadimitriou N., Gorini C., Nader F.H., Deschamps R., Symeou V., Lecomte J.C. (2018) Tectono-stratigraphic evolution of the western margin of the Levant Basin (offshore Cyprus), Mar. Petrol. Geol. 91, 683-705.

Peters K.E. (1986) Guidelines for evaluating petroleum source rock using programmed pyrolysis, AAPG Bull. 70, 3, 318-329.

Peters K.E., Walters C.C., Moldowan J.M. (2005) The biomarker guide volume 2 biomarkers and isotopes in petroleum exploration and Earth history, Cambridge University Press, Cambridge, pp. 483-631.

Pillot D., Deville E., Prinzhofer A. (2014) Identification and quantification of carbonate species using Rock-Eval pyrolysis, Oil Gas Sci. Technol. - Rev. IFP Energies nouvelles 69, 2, 341-349.

Premoli-Silva I., Premoli-Silva I., Spezzaferri S., D'angelantonio A. (1998) Cretaceous foraminiferal bio-isotope stratigraphy of Hole 967E and Paleogene planktonic foraminiferal biostratigraphy of Hole 966F, eastern Mediterranean, Proceedings of the Ocean Drilling Program. Scientific results, Vol. 160, Ocean Drilling Program, pp. 377-394.

Ratner M. (2016) Natural gas discoveries in the Eastern Mediterranean, Congressional Research Service, Washington, DC, pp. 1-15.

Rice D.D., Claypool G.E. (1981) Generation, accumulation, and resource potential of biogenic gas, AAPG Bull. 65, 1, 5-25.

Roberts G., Peace D. (2007) Hydrocarbon plays and prospectivity of the Levantine Basin, offshore Lebanon and Syria from modern seismic data, GeoArabia 12, 99-124.

Robertson A.H.F. (1998a) Mesozoic-tertiary tectonic evolution of the easternmost Mediterranean area: integration of marine and land evidence, Proceedings of the Ocean Drilling Program. Scientific results, Vol. 160, Ocean Drilling Program, pp. 723-782.

Robertson A.H.F. (1998b) Miocene shallow-water carbonates on the Eratosthenes Seamount, easternmost Mediterranean Sea, Proceedings of the Ocean Drilling Program. Scientific results, Vol. 160, Ocean Drilling Program, pp. 419-436.

Robertson A.H.F. (1998c) Lithofacies evidence for the Cretaceous-Paleogene sedimentary history of Eratosthenes Seamount, Eastern Mediterranean, in its regional tectonic context (sites 966 and 967), Proceedings of the Ocean Drilling Program. Scientific results, Vol. 160, Ocean Drilling Program, pp. 403-418.

Robertson A.H.F., Parlak O., Ustaömer T. (2012) Overview of the Palaeozoic-Neogene evolution of Neotethys in the Eastern Mediterranean region (southern Turkey, Cyprus, Syria), Petrol. Geosci. 18, 381-404. 
Sachse V.F., Littke R., Jabour H., Schümann T., Kluth O. (2012) Late Cretaceous (late Turonian, Coniacian and Santonian) petroleum source rocks as part of an OAE, Tarfaya Basin, Morocco, Mar. Petrol. Geol. 29, 1, 35-49.

Scalan E.S., Smith J.E. (1970) An improved measure of the oddeven predominance in the normal alkanes of sediment extracts and petroleum, Geochim. Cosmochim. Acta 34, 5, 611-620.

Schauder R., Kröger A. (1993) Bacterial sulphur respiration, Arch. Microbiol. 159, 6, 491-497.

Schenk C.J., Kirschbaum M.A., Charpentier R.R., Klett T.R., Brownfield M.E., Pitman J.K., Tennyson M.E. (2010) Assessment of undiscovered oil and gas resources of the Levant Basin Province, Eastern Mediterranean, US Geol. Surv. Fact Sheet 3014, 1-4.

Segev A., Rybakov M. (2010) Effects of Cretaceous plume and convergence, and Early Tertiary tectonomagmatic quiescence on the central and southern Levant continental margin, $J$. Geol. Soc. 167, 4, 731-749.

Sestini G. (1989) Nile Delta: a review of depositional environments and geological history, Geol. Soc. London S.P. 41, 1, 99-127.

Shaaban F., Lutz R., Littke R., Bueker C., Odisho K. (2006) Source-rock evaluation and basin modeling in NE Egypt (NE Nile Delata and northern Sinai), J. Petrol. Geol. 29, 2, 103-124.
Staerker S.T. (1998) Data Report: Biostratigraphy of Eocene and Upper Cretaceous chalks from the Eratosthenes Seamount region in the Eastern Mediterranean, Proceedings of the Ocean Drilling Program. Scientific results, Vol. 160, Ocean Drilling Program, pp. 395-402.

Stolper D.A., Lawson M., Davis C.L., Ferreira A.A., Neto E.S., Ellis G.S., Lewan M.D., Martini A.M., Tang Y., Schoell M., Sessions A.L., Eiler J.M. (2014) Formation temperatures of thermogenic and biogenic methane, Science 344, 6191, 1500-1503.

Suess E., Thiede J. (eds) (1983) Coastal upwelling its sediment record: Part A: Responses of the sedimentary regime to present coastal upwelling, Plenum Press, New York.

Symeou V., Homberg C., Nader F.H., Darnault R., Lecomte J.C., Papadimitriou N. (2018) Longitudinal and temporal evolution of the tectonic style along the Cyprus arc system, assessed through 2-D reflection seismic interpretation, Tectonics 37, 1, 30-47.

Tissot B.P., Welte D.H. (1984) Petroleum Formation and occurrence, Springer, Berlin.

Vandré C., Cramer B., Gerling P., Winseman J. (2007) Natural gas formation in the western Nile delta (Eastern Mediterranean): Thermogenic versus microbial, Org. Geochem. 38, 4, $523-539$. 